\title{
CONTINUIDAD PÚNICA EN LA GADES REPUBLICANA. LA PRODUCCIÓN VASCULAR DEL HORNO DE LA CALLE TROILO*
}

\author{
PUNIC CONTINUITY IN REPUBLICAN GADES. CERAMIC VESSELS \\ PRODUCTION FROM TROILO STREET KILN CERAMICS
}

\author{
ANA Ma NIVEAU DE VILLEDARY Y MARIÑAS ${ }^{* *}$ \\ FRANCISCO J. BLANCO JIMÉNEZ ${ }^{* * *}$
}

Resumen: La excavación de un horno "de praefurnium escalonado" de pequeñas dimensiones en el casco antiguo de la actual ciudad de Cádiz matiza, gracias a la producción vascular asociada -en su gran mayoría piezas de la vajilla fina republicana y en menor medida terracotas y askoi zoomorfos-, la cronología de uso de estas estructuras de combustión tardopúnicas; y permite, una vez más, defender la continuidad cultural púnica en la ciudad de Gades hasta prácticamente el cambio de era. Palabras claves: horno alfarero - vajilla republicana - terracotas figuradas - askoi zoomorfos - ss. II-I a.C.

\section{INTRODUCCIÓN}

La intensificación de las intervenciones arqueológicas en el casco urbano de la actual ciudad de Cádiz como consecuencia de la normalización y puesta

* Este trabajo se inscribe en el marco de actuación del Grupo de Investigación "Phoenix Mediterranea». Protohistoria del Mediterráneo Occidental (HUM-509), dentro del IV Plan Andaluz de Investigación, dirigido por el Dr. Diego Ruiz Mata y de los Proyectos de I+D financiados por el Ministerio de Ciencia e Innovación Tinnit en Ibiza: la cueva Des Culleram (HUM2007-63574) Los fenicios occidentales: sociedad, instituciones y relaciones politicas (siglos VIIII a.C.) (HAR2008-03806/HIST) dirigidos por la Dra. M. ${ }^{a}$ C. Marín Ceballos y el Dr. J.L. López Castro, respectivamente.

** Investigadora "Ramón y Cajal". Departamento de Historia, Geografía y Filosofía. Facultad de Filosofía y Letras. Avda. Gómez Ulla s/n. 11003 - Cádiz (España).E-mail: anamaria.niveau@uca.es. *** Arqueólogo de PROCASA. Director de la intervención.
Abstract: The excavation of a small praefurnium furnace in terraces in the city centre of the present city of Cadiz, adjusts, thanks to the ware production associated to it -mainly pieces from the republican fine tableware and, partly, terracotte and zoo form askoi-, the chronology of use of these late Punic structures of combustion. The excavation also allows, once more, backing the continued existence of Punic culture in Gades until the change of era.

Keywords: pottery furnace - republican fine tableware - figured terracotte - zoo form askoi $-2^{\text {nd }}-1^{\text {st }}$ centuries B.C.

en práctica de la llamada "Arqueología de Urgencia" o "Arqueología Urbana" en las últimas décadas, ha generado que la información disponible sobre la época fenicio-púnica y romana de la ciudad se multiplique de forma extraordinaria; no obstante, este incremento de datos no ha llevado parejo un mayor conocimiento de estas etapas históricas pues salvo contadas excepciones los resultados se limitan a la presentación de los correspondientes informes y memorias ante la Administración responsable o en el mejor de los casos merecen una nota breve en los Anuarios que resumen la actividad arqueológica anual de la comunidad Andaluza ${ }^{1}$. La consecuencia inmediata es la pérdida de toda esta información que ante la falta de publicación pocas veces

1. Publicados a fecha de hoy hasta el año 2003 inclusive. 


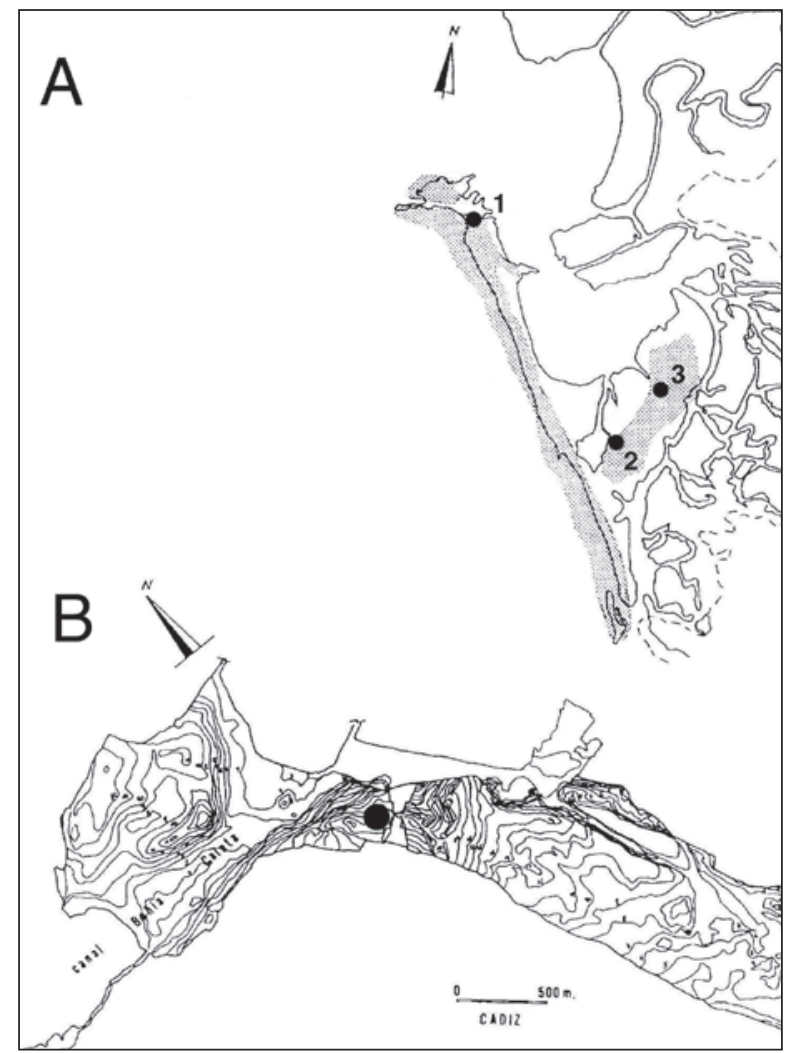

Figura 1: A. Situación de los alfares citados en el texto. 1. C/ Troilo ${ }^{\circ} 5$ (Cádiz, casco urbano-intramuros). 2. La Milagrosa (San Fernando, Cádiz). 3. Torre Alta (San Fernando, Cádiz). B. Situación del yacimiento.

llega al resto de la comunidad científica (Vallejo y Niveau de Villedary 1999, 2001 y 2002).

Aportando nuestro particular grano de arena, en este trabajo presentamos ahora los resultados de una de estas actuaciones urbanas de urgencia llevada a cabo por uno de nosotros a comienzos de 1999 (Blanco 1999a).

El solar objeto de la intervención se sitúa en la zona intramuros de la ciudad de Cádiz, en el actual Barrio de Santa María (Fig. 1), zona catalogada como de alta densidad arqueológica ${ }^{2}$. Los trabajos sacaron a la luz un horno alfarero de tradición tardopúnica en cuyo interior aún se conservaban las últimas hornadas producidas y

2. De acuerdo al Plan General de Ordenación Urbana de Cádiz, la ciudad se divide en zonas según la densidad arqueológica definida por una carta de riesgo. Cada zona implica la obligación, ante cualquier remoción de tierras, de una actuación arqueológica que se adecue a las previsiones; la catalogación como zona de Grado 1 se traduce en la obligatoriedad de realizar sondeos arqueológicos por cada $100 / 150 \mathrm{~m}^{2}$ (y en su caso excavar) en aquellos niveles que se vean afectados por la construcción de nuevos edificios ( $c f$. P.G.O.U. de Cádiz, B.O.P. de Cádiz, nº 287, 14 diciembre 1995, Art. 4.6.3). una pequeña oquedad adosada al praefurnium, probablemente la fosa de vertido del alfar, que mostraba un importante nivel de cenizas y algunos restos materiales cerámicos.

La importancia del conjunto radica, por una parte, en la constatación arqueológica de las pervivencias púnicas en la ciudad de Cádiz durante buena parte del periodo republicano, patentes tanto en la tipología del horno como en algunos de los materiales que se fabricaron en él, sobre todo los askoi zoomorfos y los llamados "pebeteros en forma de cabeza femenina" (Niveau de Villedary 2007: 168-173); y, por otra, en la posible relación de esta zona industrial con la vecina necrópolis, a la que iría destinada gran parte de la producción vascular según apuntan las formas fabricadas.

\section{LOS HORNOS DE "PRAEFURNIUM ESCALONADO”. TIPOLOGÍA Y CRONOLOGÍA}

La intensa actividad arqueológica desarrollada en los últimos años en el término municipal de San Fernando $(\mathrm{Cádiz})^{3}$ ha supuesto que de prácticamente no conocer nada de lo que sucedía en la tercera isla del antiguo archipiélago gaditano, en la actualidad ésta aparezca ante nosotros como el auténtico "barrio alfarero" de Gadir (Bernal et alii 2003: 95), en el sentido que lo definen Mannoni y Giannichedda (2004: 280-281).

En efecto, hasta la aparición de los dos primeros hornos de Torre Alta en 1987 (Perdigones y Muñoz 1990; Frutos y Muñoz 1994) sólo se tenían una serie de noticias vagas que apuntaban a la existencia de una industria alfarera púnica en la zona de Gallineras y el Cerro de los Mártires. Los primeros datos proceden de las excavaciones realizadas por Pelayo Quintero a comienzos del s. XX (1932: 13-23), si bien la información es confusa; con posterioridad, tuvieron lugar una serie de actuaciones arqueológicas que conocemos únicamente por breves notas o por referencias indirectas (Sáez Espligares 1994; Sáez Romero et alii 2003: 167; Bernal et alii 2003: 19-23); mientras que en los últimos años, gracias a un renovado impulso de los trabajos de campo y al esfuerzo editorial, se han multiplicado de forma extraordinaria los sitios conocidos (por último, entre otros, Bernal y Lagóstena eds. 2004).

Esta producción alfarera a gran escala se orienta principalmente a la fabricación de envases anfóricos en relación con la floreciente industria salazonera

3. En este sentido resultan ilustrativos los trabajos presentados a dos reuniones científicas de reciente publicación, $c f$. VV.AA. 2004 y Bernal y Lagóstena eds. 2004. 
gaditana que se desarrolla en época púnica (Muñoz, Frutos y Berriatúa 1988; Frutos y Muñoz 1996; Muñoz y Frutos 2004; García Vargas 2001; García Vargas y Ferrer 2001; Ruiz Gil 1987 y 1991; Vallejo, Córdoba y Niveau de Villedary 1999) y perdura durante todo el período romano (Lagóstena 2001). Ahora bien, el desarrollo de los trabajos ha mostrado que ésta no es exclusiva, ya que junto a los hornos de mayores dimensiones aparecen con relativa frecuencia otros de menor tamaño destinados a la fabricación de vajilla doméstica (Frutos y Muñoz 1994: 398; Gago et alii 2000: 43; Castañeda y Herrero 2001: 135) y objetos votivo-religiosos de terracota (Ferrer 1995-96: 66; Ferrer, Sibón y Mancheño 2000: 596; Bernal et alii 2003: 58-62, 6970, 230-237, figs. 11, 13, 16, 20; Sáez, Montero y Toboso 2004: 210).

A pesar de que todos los indicios apuntan a que sería en la actual isla de León -la Antípolis de las fuentes- donde se localizaría el barrio industrial y alfarero que abastecía a gran parte de la bahía de Cádiz, también en las otras islas e incluso en tierra firme se ha podido constatar la existencia de una producción cerámica a escala menor y quizás también con fines más concretos. De hecho, han aparecido alfares tanto en la menor de las islas gaditanas -la llamada Erytheia, situada al norte del canal que separaba ambas islas-, en este caso también en relación con la producción de salazones y en funcionamiento entre el s. I a.C y el I d.C. (Blanco 1991; Frutos y Muñoz 1996: 137-138, figs. 4 y $10, A)$, como en la mayor -Kotinoussa-; al menos eso interpretan Frutos y Muñoz por la aparición, en una zona de la necrópolis púnica y romana, de ánforas locales deformes por defectos de fabricación (Frutos y Muñoz 1996: 140, fig. 10, B; Muñoz y Frutos 2004: 154). Otras actuaciones en la isla mayor han permitido verificar la existencia de alfares, centrados ya en época republicana, como el de Avda. de Portugal (Bernal et alii 2004a), y altoimperial -Avda. de Andalucía (Blanco 1999a: 19)-

Junto a éstos, conocemos la existencia de un posible horno de producción cerámica -quizás un secadero- procedente de los últimos niveles de habitación -s. III a.C.- de la ciudad fenicia del Castillo de Doña Blanca ${ }^{5}$ situada al otro lado de la bahía, que muy probablemente haya que poner en relación con el autoabastecimiento de la propia ciudad. También en el término

4. En relación con algunas producciones concretas, en este caso la vajilla de tipo helenístico local de "tipo Kuass", vid. Niveau de Villedary 2004a y $2004 b$.

5. Dato inédito que agradecemos a sus excavadores, D. Ruiz Mata y C. J. Pérez. municipal de El Puerto de Santa María y formando parte de un complejo industrial púnico de mayores dimensiones destinado a la transformación de los productos del mar, documentamos otra estructura de combustión, en muy mal estado de conservación, en la llamada factoría "Puerto 19" (Gutiérrez 2000: 20) que, no obstante, también ha sido relacionada con la propia elaboración de las salsamenta (Gutiérrez 2001: 84) o incluso con una posible actividad metalúrgica (Gutiérrez 2001: 82).

Con posterioridad, ya en época romana, se advierte una cambio en la implantación territorial de las industrias alfareras, que ahora se ubican preferentemente al otro lado de la bahía, extendiéndose por todo el territorio de El Puerto de Santa María y Puerto Real, multiplicándose las figlinae de forma extraordinaria (Lagóstena 1994 y 1996; García Vargas 1998; Lagóstena y Bernal 2004).

Toda esta información ha permitido caracterizar la facies productiva gaditana desde el s. VI a.C. hasta época tardoimperial, determinar la secuencia evolutiva de las producciones locales occidentales: ánforas y vajilla fina de mesa y, en definitiva, que hoy conozcamos mejor la organización y estructuración de los alfares. En este sentido cobra especial importancia la documentación de tipologías de hornos que hasta ahora parecen exclusivas de mundo púnico occidental, hablamos de los llamados "hornos de praefurnium escalonado" definidos a partir de algunas estructuras isleñas (Bernal et alii 2003: 188-201 y 2004b) y a la que también pertenece el alfar objeto de este trabajo.

\section{II.1. EI modelo tardopúnico. Las estructuras de Torre Alta y La Milagrosa (San Fernando, Cádiz) (Fig. 1)}

En general, los hornos isleños se corresponden con modelos próximo-orientales difundidos a Occidente por los fenicios, de los que encontramos ejemplos a lo ancho y largo del Mediterráneo (Frutos y Muñoz 1994: 396-398; Gago et alii 2000: 43-45).

Aunque los tipos varían desde las simples cámaras circulares - Horno II de La Milagrosa (Bernal et alii 2003: 201-205, figs. 36-38), horno 5 de Camposoto (Gago et alii 2000: 40-41), ¿Residencial David ${ }^{6}$ ? (Clavaín y Sáez 2003: 176-177)- hasta los más evolucionados de planta en "U" o piriformes, pasando por los

6. La estructura se halló muy destruida, aunque los autores creen ver huellas del posible praefurnium en la existencia de un estrecho canal que parte del horno radialmente (Clavaín y Sáez 2003: 177). 
hornos de tipo "omega" documentados en el Sector III de Camposoto (Gago et alii 2000: 41, fig. 3), la mayoría responde a las mismas características constructivas.

El primer paso consiste en excavar las estructuras en el firme natural para a continuación forrar las paredes de lo que será la cámara de combustión mediante tapiales, a veces reforzados con adobes y piedras (Frutos y Muñoz 1994: 395-396) o bien con placas de adobes de diferentes formas y tamaños (Gago et alii 2000: 41; Arteaga et alii 2001: 131; Sáez Romero et alii 2004: 102) e incluso se utiliza material cerámico apelmazado (Gago et alii 2000: 42; Bernal et alii 2003: 200), aunque lo más frecuente es el uso de sucesivas capas de arcillas, que aparecen rubefactadas por la acción continuada del calor (Frutos y Muñoz 1994: 395; Gago et alii 2000: 40; González Toraya et alii 2000: 177; Arteaga et alii 2001: 131; Bernal et alii 2003: 194; Clavaín y Sáez 2003: 177).

Habitualmente, la parte superior de los hornos, es decir la parrilla y la cámara de cocción, no se conserva; en el mejor de los casos sus restos aparecen desplomados en el interior de la cámara de combustión, por lo que es posible reconstruir cómo serían originalmente. Una excepción la constituye el conjunto de hornos excavados en el Sector III de Camposoto, algunos de los cuáles conservan la parrilla intacta e incluso parte de la cámara de cocción, que en este caso se levanta con arcillas (Gago et alii 2000: 40 y 42).

En general, las estructuras responden al modelo de horno de pilar central (Mannoni y Giannichedda 2004: fig. 34), que en los tipos más antiguos presenta planta elíptica y se une a la pared mediante un contrafuerte (Gago et alii 2000: 40-41, figs. 2-3) y en los más recientes es circular y exento -formado por tambores circulares de piedra ostionera local (Frutos y Muñoz 1994: 395), adobes radiales (Blanco 1999a: 8; Sáez Romero et alii 2004: 102) o arcilla (Bernal et alii 2003: 196)-. Las paredes se unen al pilar mediante arcos de medio punto, de los que normalmente sólo se conservan los arranques que son los que sustentan la parrilla, formada por una falsa bóveda de ladrillos plano-convexos trabados con arcilla (Frutos y Muñoz 1994: 395).

Siguiendo la línea evolutiva trazada tanto por la propia tipología de las estructuras como por la cronología de los materiales asociados, los últimos hornos serían los de planta piriforme y pilar central exento. Definidos en un primer momento a partir de los hallazgos de Torre Alta (Perdigones y Muñoz 1990), se han documentado en las sucesivas intervenciones que han tenido lugar tanto en el propio yacimiento (Arteaga et alii 2001; Sáez Romero 2004; Sáez Romero et alii 2004) como en el vecino alfar de Pery Junquera (González Toraya et alii 2000: fig. 1).
Ahora bien, algunas de estas estructuras presentan una particularidad constructiva ${ }^{7}$ que es la que ha permitido definir el nuevo tipo. En líneas generales se trata de crear dos alturas diferentes en la cámara de combustión: mientras que la posterior queda más elevada, la delantera desde el praefurnium hasta la columna central va decreciendo, de manera que entre ambas zonas se crea un escalón de altura variable -entre 30-40 cms. en La Milagrosa, $21 \mathrm{cms}$. en Troilo-. Este desfase se ha explicado como una mejora funcional, se trata de concentrar el calor -en este caso es la parte anterior, más profunda, la que alcanza mayores temperaturas- para que acceda a la cámara de cocción con mayor intensidad (Bernal et alii 2003: 195), lo que unido a otras modificaciones, como la reducción de las propias estructuras de combustión, permitiría un mejor paso del calor a todas las zonas de la cámara de cocción, produciendo una mejora en el rendimiento general de la estructura (Bernal et alii 2003: 200).

Por ahora, se trata de una tipología sólo documentada en la bahía de Cádiz (Bernal et alii 2004b: 616), en la que se incluirían los Hornos I y II de la intervención de 1997 en Avda. Al-Andalus (Fig. 2, 1), el no 5 de Torre Alta (Sáez Romero 2004: fig. 9; Sáez Romero et alii 2004: 103), y la estructura documentada en La Milagrosa (Fig. 2, 2).

Los materiales recuperados en los niveles que colmatan las estructuras -ánforas gaditanas T-9.1.1.1. evolucionadas e imitaciones locales de campaniense A tardía- fechan el último período de funcionamiento de los hornos de Avda. Al-Andalus a mediados (Bernal et alii 2004b: 616) o hacia el último tercio (Sáez Romero 2004: 709) de la segunda centuria antes de la era, aunque sus excavadores lo prolongaban hasta la última década del siglo (ca. 100 a.C.) (Arteaga et alii 2001: 132); mientras que la presencia de algunos bordes de T-8.2.1.1. en el relleno del horno de La Milagrosa permiten sostener que estuvo en funcionamiento hacia

7. A la luz de la revisión detallada de las publicaciones sobre las primeras intervenciones arqueológicas en Torre Alta, nos preguntamos si tal particularidad constructiva -el "praefurnium escalonado"advertida en las últimas estructuras excavadas, es decir en los dos hornos de Avda. Al-Andalus (Arteaga et alii 2001), en el horno 5 de Torre Alta (Sáez Romero 2004: 705) y en el de La Milagrosa (Bernal et alii 2003: 194-198), no es, en realidad, una característica de todas estas estructuras, ya que los primeros hornos de Torre Alta se describen de la siguiente manera: "el suelo de la cámara está dispuesto en rampas a ambos lados de la columna hacia el corredor, al que se accede mediante escalones" (Frutos y Muñoz 1994: 395; la cursiva es nuestra); aunque es cierto que este detalle no se representa ni en las plantas, ni en las secciones de dichas estructuras (Frutos y Muñoz 1994: figs. 3 y 4; tampoco aparece en Pery Junquera: González Toraya et alii 2000: fig. 1). 

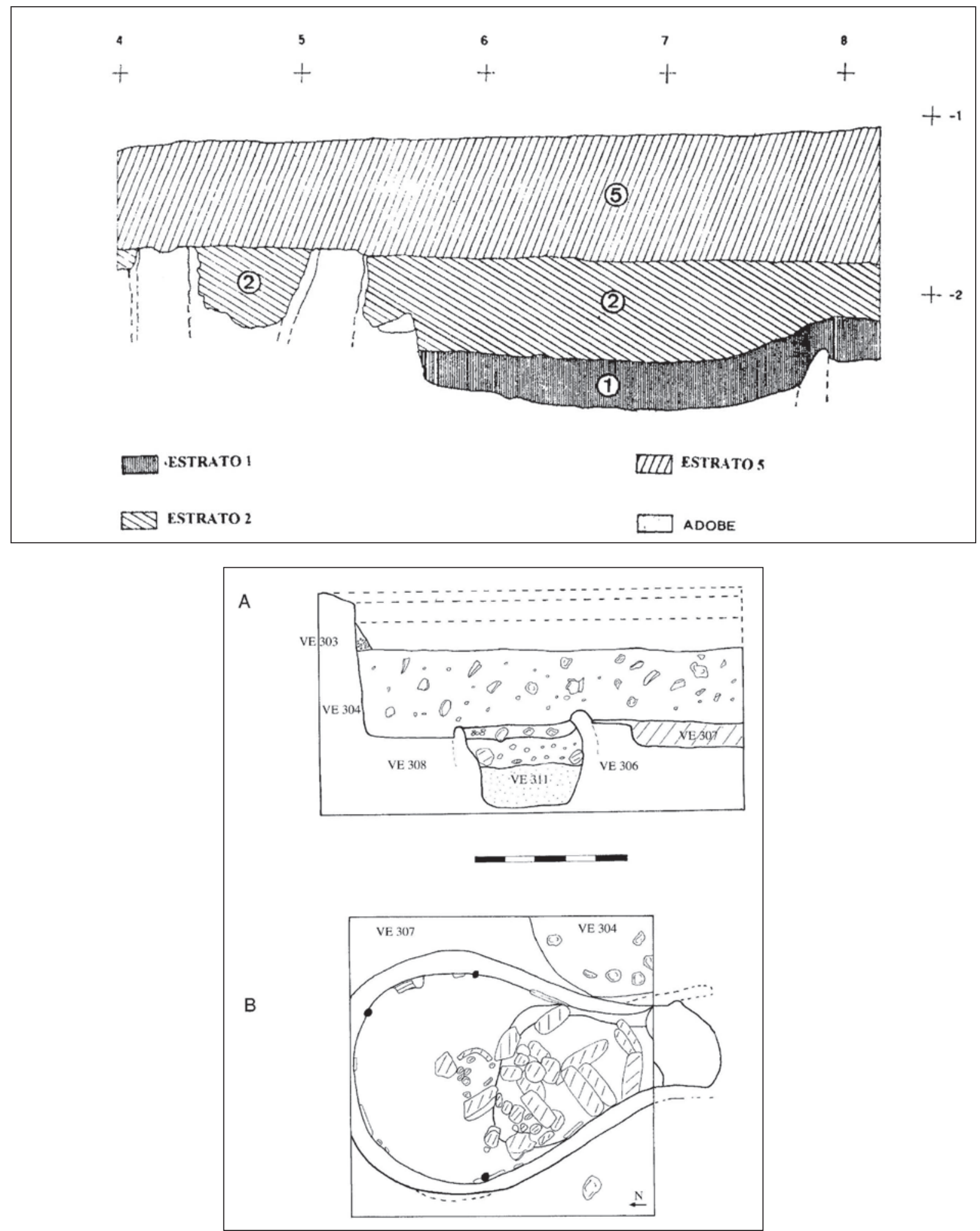

Figura 2: 2,1. Alzado del horno I de Avda. de Al-Andalus, procedente de la tercera intervención arqueológica en el entorno del yacimiento de Torre Alta (1997) (Según Arteaga et alii 2001: fig. 3). 2,2. Estratigrafía y planta del Horno I de la Milagrosa (Según Bernal et alii 2003: fig. 29). 
finales del s. III y comienzos del II a.C. (ca. 200 a.C.) (Bernal et alii 2003: 199, fig. 31, 2-3). Por la aparición mayoritaria de T-9.1.1.1., T-8.2.1.1 y T-12.1.1.1/2 se propone una cronología para el último horno, excavado en el 2003 (Sáez Romero 2004), en torno a la finalización de la II Guerra Púnica (ca. 206 a.C.) (Bernal et alii 2003: 200), en cualquier caso nunca más allá del 200 a.C. (Sáez Romero 2004: 705).

La similitud cronológica de los casos documentados llevó en un primer momento a relacionar esta innovación técnica con el paso de Gadir a la órbita romana (Bernal et alii 2003: 200), aunque en un trabajo posterior y ante la constatación de la escasa vigencia de la tipología, que no parece traspasar la conquista romana, los mismos autores se decantan ahora por la defensa de un origen púnico-gadirita (Bernal et alii 2004b: 607) y por la no continuidad de los hornos de praefurnium escalonado en momentos romanos.

\section{II.2. Posibles pervivencias. EI horno gaditano de Calle Troilo (Fig. 3; Lám. I)}

Con motivo del estudio pormenorizado de la intervención de urgencia llevada a cabo a comienzos de 1999 en la calle Troilo (Blanco 1999a) y tras la revisión de la estructura de combustión documentada en el cuadro A-1 y de los materiales que la colmatan, podemos apuntar que todavía en la primera mitad del s. I a.C. estaban en funcionamiento este tipo de hornos - posiblemente de forma residual- en los pequeños alfares que se situarían en la periferia del centro urbano, seguramente en relación con la necrópolis.

Se trata de un horno de pequeñas dimensiones que se abandonó por el hundimiento de las estructuras superiores con la última hornada en su interior, vasos cerámicos de pequeño tamaño; lo que ha permitido comprobar, una vez más, la diversificación funcional documentada desde la excavación de los primeros hornos de Torre Alta.

El horno apareció en el perfil que separaba el solar de la finca colindante y a pesar de los esfuerzos sólo se pudo excavar la mitad de la estructura, ya que el resto atravesado a su vez por un muro romano de época posterior- quedaba bajo ésta; mientras que el lateral opuesto se hallaba afectado por una zanja romana también más moderna. Las paredes y la base de cimentación del horno la forman el propio terreno natural de greda verdosa caliza. La planta presenta forma subcuadrangular, con los extremos redondeados. La parte delantera de la cámara de combustión es en realidad una prolongación del estrecho pasillo o praefurnium -de poco más de un metro de largo por $23 \mathrm{~cm}$. de ancho- que desciende a

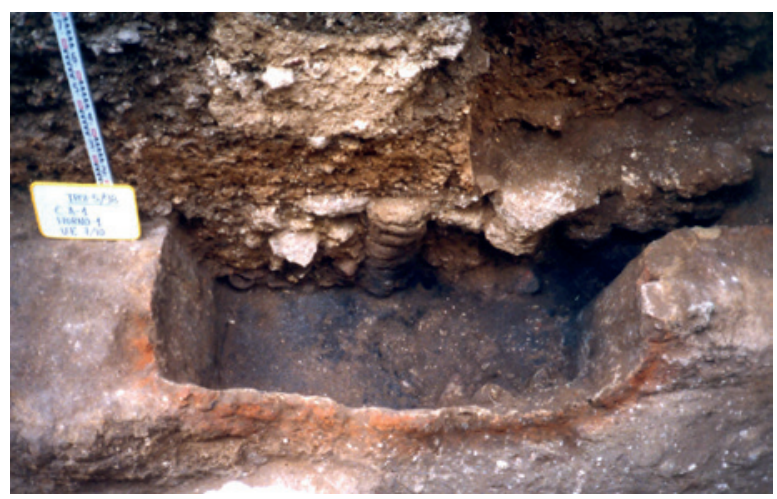

Lámina I: Horno de la C/ Troilo (Fotografía: Francisco J. Blanco Jiménez).

modo de rampa hasta el centro de la cámara donde se encuentra el pilar central, parcialmente destruido y formado por seis piezas circulares o tambores de arcilla, algo deformados por las altas temperaturas soportadas; a partir de éste el suelo se eleva bruscamente, formando un escalón de unos $21 \mathrm{cms}$. de altura. Tanto la parte superior de la cámara de combustión como la parrilla y consecuentemente la cámara de cocción han desaparecido, aunque al fondo de la cámara de combustión se conservan parte de los arcos de la bóveda que sostendría la parrilla. El material constructivo empleado son los clásicos adobes plano-convexos que se documentan en otras estructuras similares (Bernal et alii 2003: figs. 31, 1; 34 y 35; Sáez Romero et alii 2004: 102).

En el extremo del praefurnium y conectada con éste se excava una especie de fosa de planta triangular que en nuestra opinión se debió utilizar como escombrera, acumulándose en ella, entre capas de ceniza, la cerámica de desecho, con fallos o mala cocción. En su interior hemos encontrado los materiales más interesante y significativos por su calidad y peculiaridad.

\section{LA PRODUCCIÓN VASCULAR DEL HORNO DE LA CALLE TROILO}

Los objetos cerámicos se concentran en dos zonas bien definidas, entre una gran cantidad de cenizas y restos de los adobes plano-convexos pertenecientes a las estructuras superiores hundidas.

Por una parte, en el fondo de la cámara de combustión y en el entronque con el praefurnium es donde se acumula el mayor número de objetos, correspondientes a los últimos tipos que se fabricaron en el horno (Fig. 4; Gráf. 1). Casi la totalidad (92\%) responde a la fabricación de dos tipos cerámicos concretos: cuencos-tapadera 


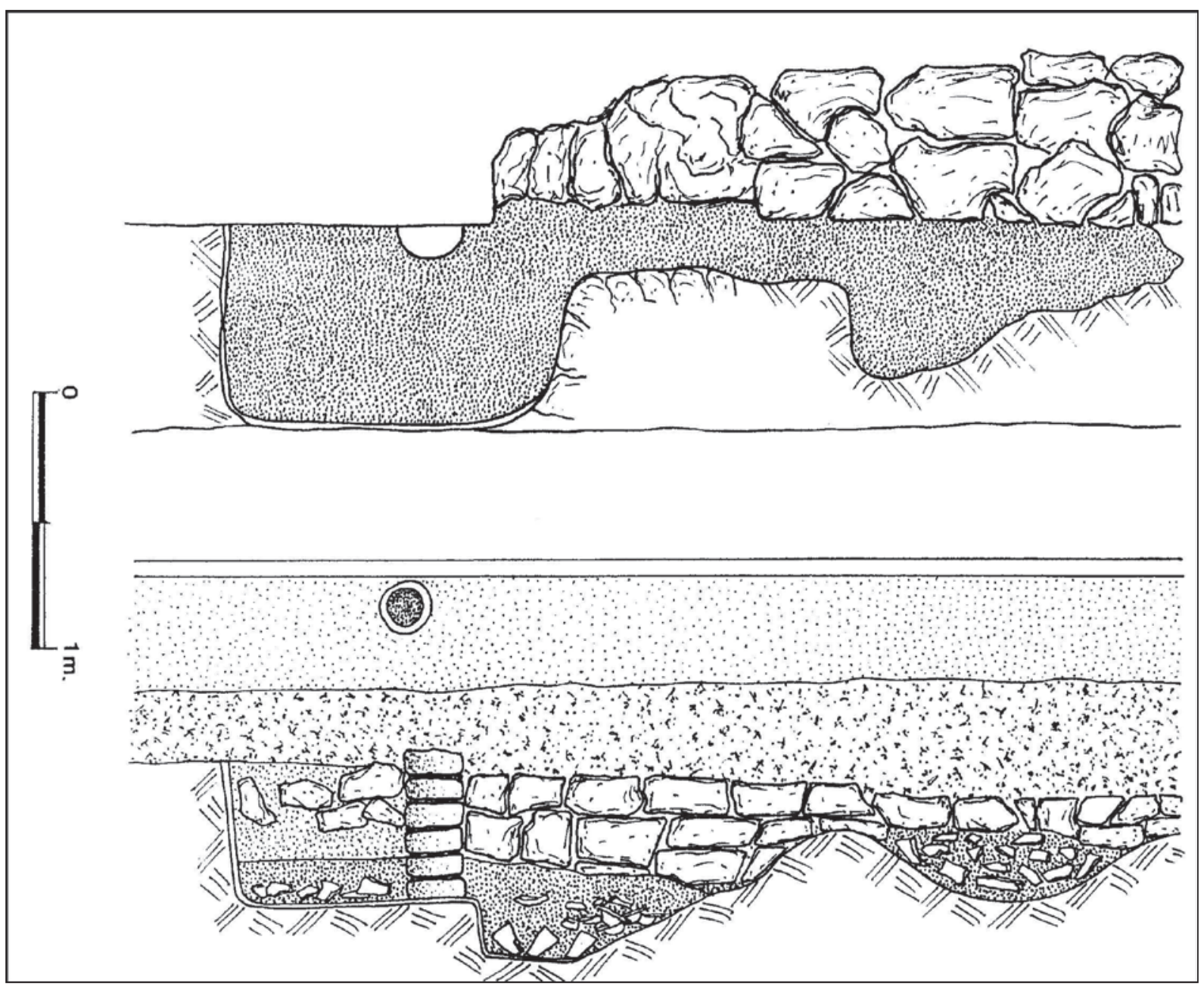

Figura 3: Planta y alzado del horno de la C/ Troilo (Dibujos: Francisco J. Blanco Jiménez).

(78\%) y recipientes troncocónicos que a falta de una denominación más precisa llamaremos "cubiletes" $(14 \%)^{8}$. En menor medida aparecen otras formas: cazuelas de borde bífido de diferentes perfiles y tamaños $(2 \%)$, opérculos $(3 \%)$ y algún fragmento aislado de terracotas y askoi figurativos (1\%). También es de destacar la presencia de dos objetos cerámicos de forma alargada y cilíndrica (Fig. 5) que hemos interpretado como separadores y que se intercalarían entre los vasos a la hora de la cocción para evitar el contacto entre ellos y

8. Estos porcentajes, no obstante, no representan con total exactitud la producción real, ya que hay que tener en cuenta que las formas más robustas de "cubiletes" aparecen en un buen número completas o casi completas, mientras que los cuencos-tapadera son mucho más susceptibles de fracturas, hallándose numerosos fragmentos, en ocasiones de pequeño tamaño. Aun así, parece claro que se trata de las dos últimas formas fabricadas en este horno. de algunas pellas informes de arcilla. El alto número de piezas completas y fragmentos hallados en el interior de la cámara de combustión ${ }^{9}$ nos lleva a pensar que éste se abandonó con las últimas hornadas en su interior (Fig. 4; Gráf. 1), posiblemente debido al hundimiento de la cámara de cocción y de la parrilla.

En segundo lugar, hallamos otra concentración cerámica, aunque en número sensiblemente inferior ${ }^{10}$, en la fosa que se abre al comienzo del praefurnium que se ha interpretado como un pequeño vertedero donde

9. En total hemos contabilizado 1.678 piezas, 242 "cubiletes", 1.313 cuencos-tapadera, 56 opérculos, 27 cazuelas de borde bífido, 13 fragmentos de terracotas y 27 fragmentos varios (entre ánforas, cazuelas, fuentes y urnas varias y algún objeto metálico).

10. En este caso las piezas recuperadas se limitan a ochenta y siete fragmentos de diversa naturaleza: las piezas más abundantes son los askoi y pebeteros (28 fragmentos de terracota) y los opérculos (28). 


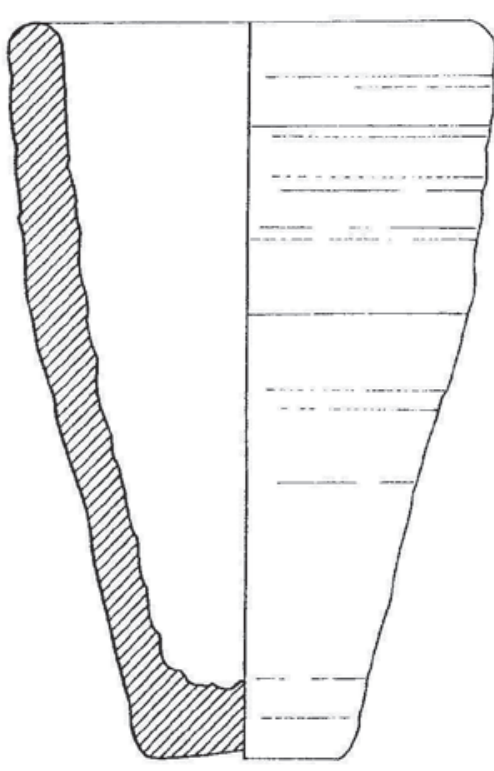

1

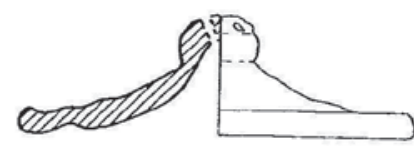

4
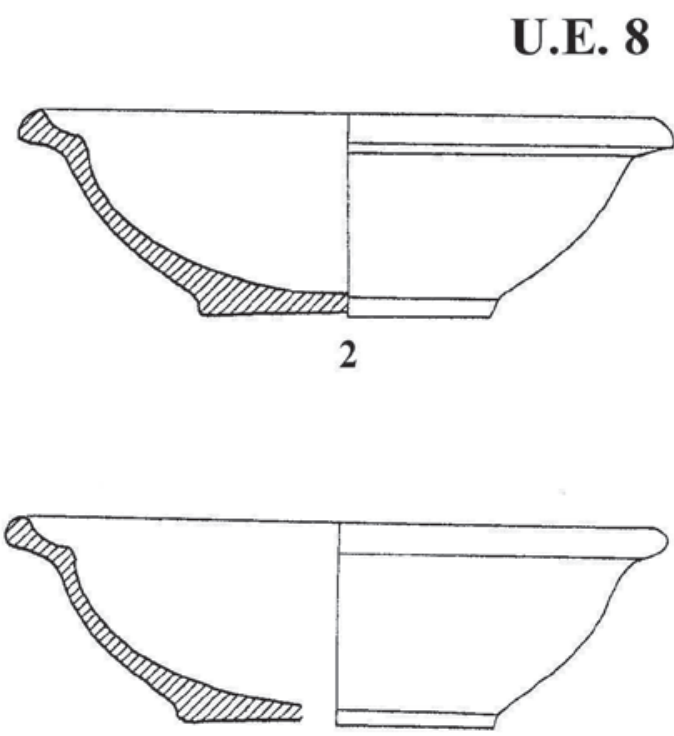

3

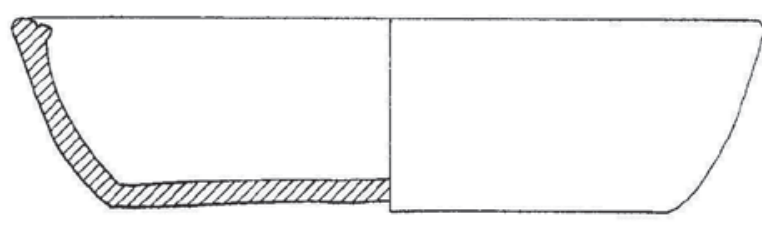

5
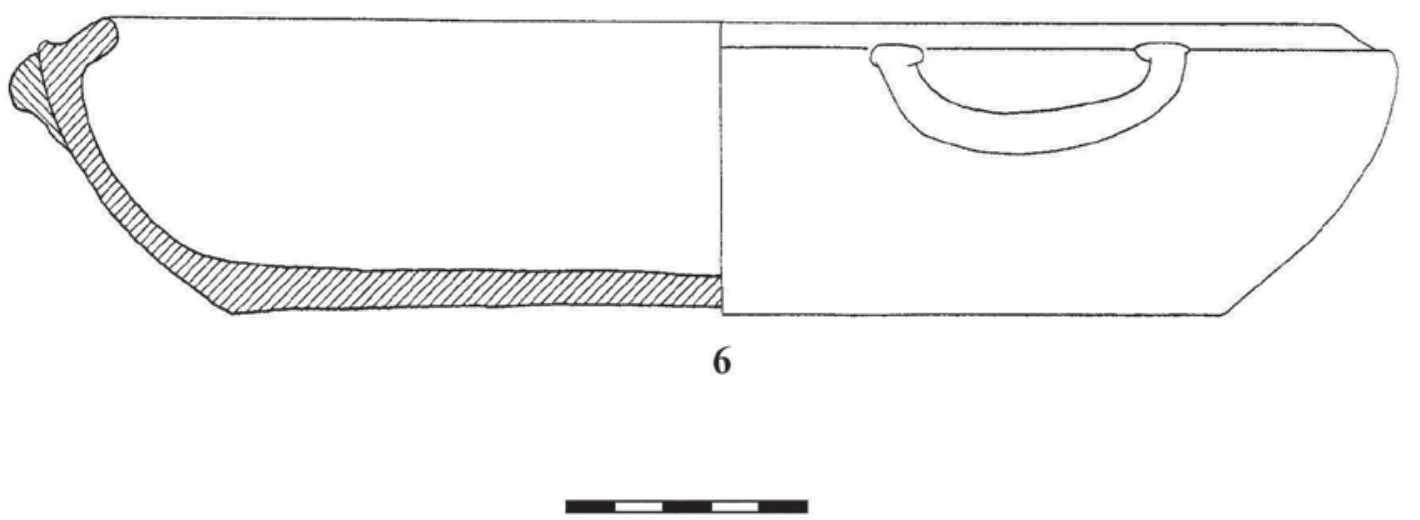

Figura 4: Vasos procedentes de la cámara de combustión correspondientes a las últimas hornadas producidas en el horno

(U.E. 8). 1. "Cubilete". 2-3. Cuencos-tapadera con escalón. 4. Opérculo. 5. Cazuela de borde bífido. 6. Cazuela (Dibujos: Ana Ma Niveau de Villedary y Mariñas). 


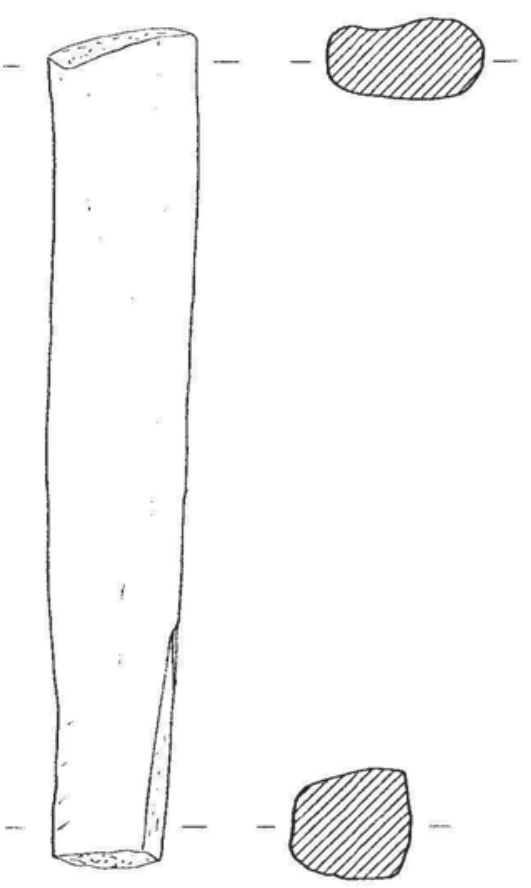

1
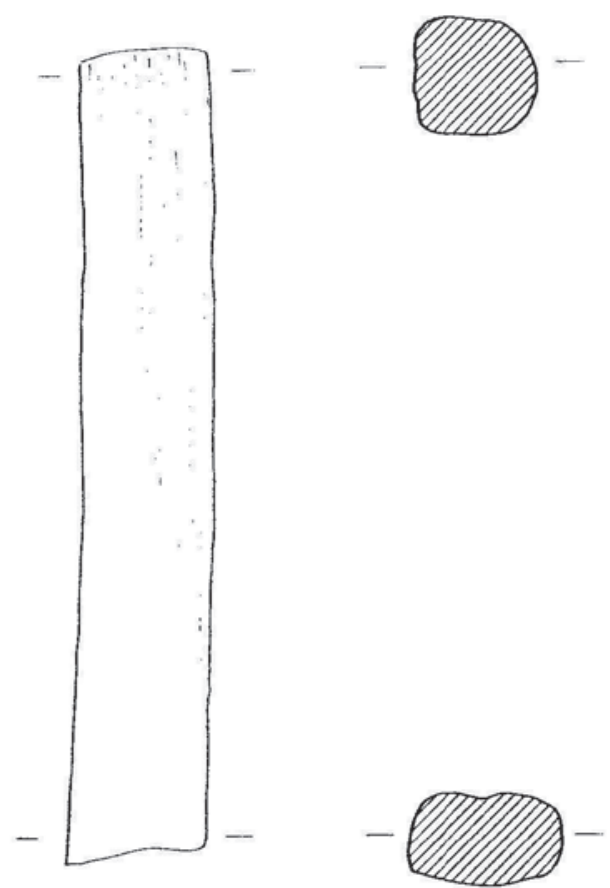

2

Figura 5: Separadores de arcilla. Interior de la cámara de combustión (U.E. 8). (Dibujos: Ana Ma Niveau de Villedary y Mariñas).

\section{U.E. 8 - CÁMARA DE COMBUSTIÓN}

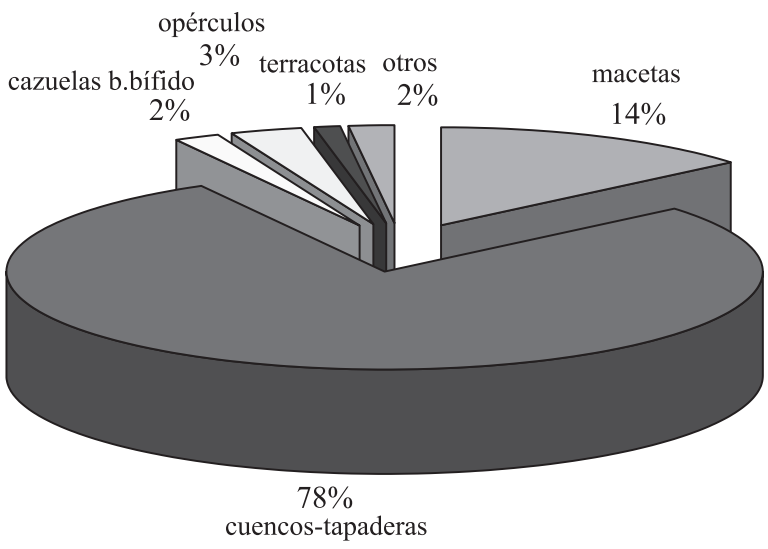

Gráfico 1: Vasos procedentes de la cámara de combustión (U.E. 8). se depositan las piezas defectuosas o desechadas. Estos materiales presentan una variedad formal (Fig. 6; Gráf. 2) mayor que los de la cámara del horno, lo que apoya la interpretación funcional que hemos hecho de la estructura. Suponemos que los materiales de esta fosa procederían del horno. A favor de esta posibilidad está el importante nivel de cenizas documentado que debía proceder de las limpiezas cíclicas de la cámara, la propia situación de la fosa, en conexión con el praefurnium, y la presencia de alguna pella de arcilla entre los materiales recuperados. En algunos casos -ya que se trata de las mismas formas documentadas en éstepodemos afirmarlo con seguridad, pero en otros cabe la posibilidad de intrusiones posteriores, de descargas de otras estructuras cercanas o de un uso más amplio como basurero por parte de los propios trabajadores del alfar.

En este caso los materiales más numerosos son los fragmentos de terracota pertenecientes a "pebeteros en forma de cabeza femenina" y askoi zoomorfos (28 fragmentos, $32 \%$ del material total) y las formas de opérculo 


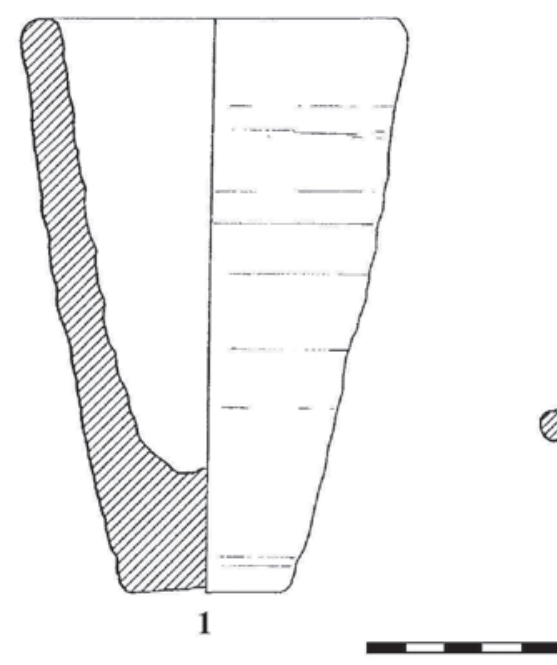

U.E. 11
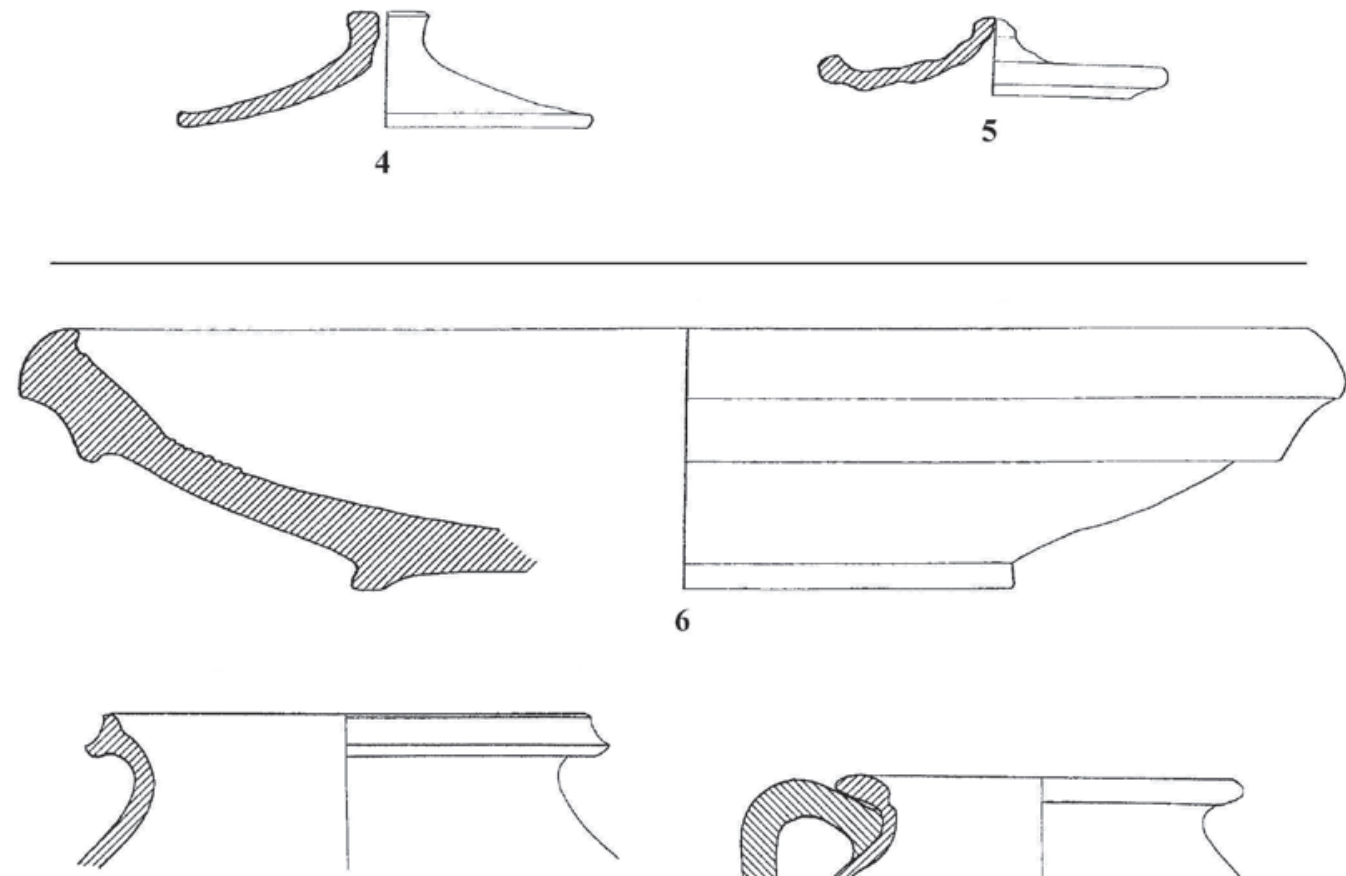

7
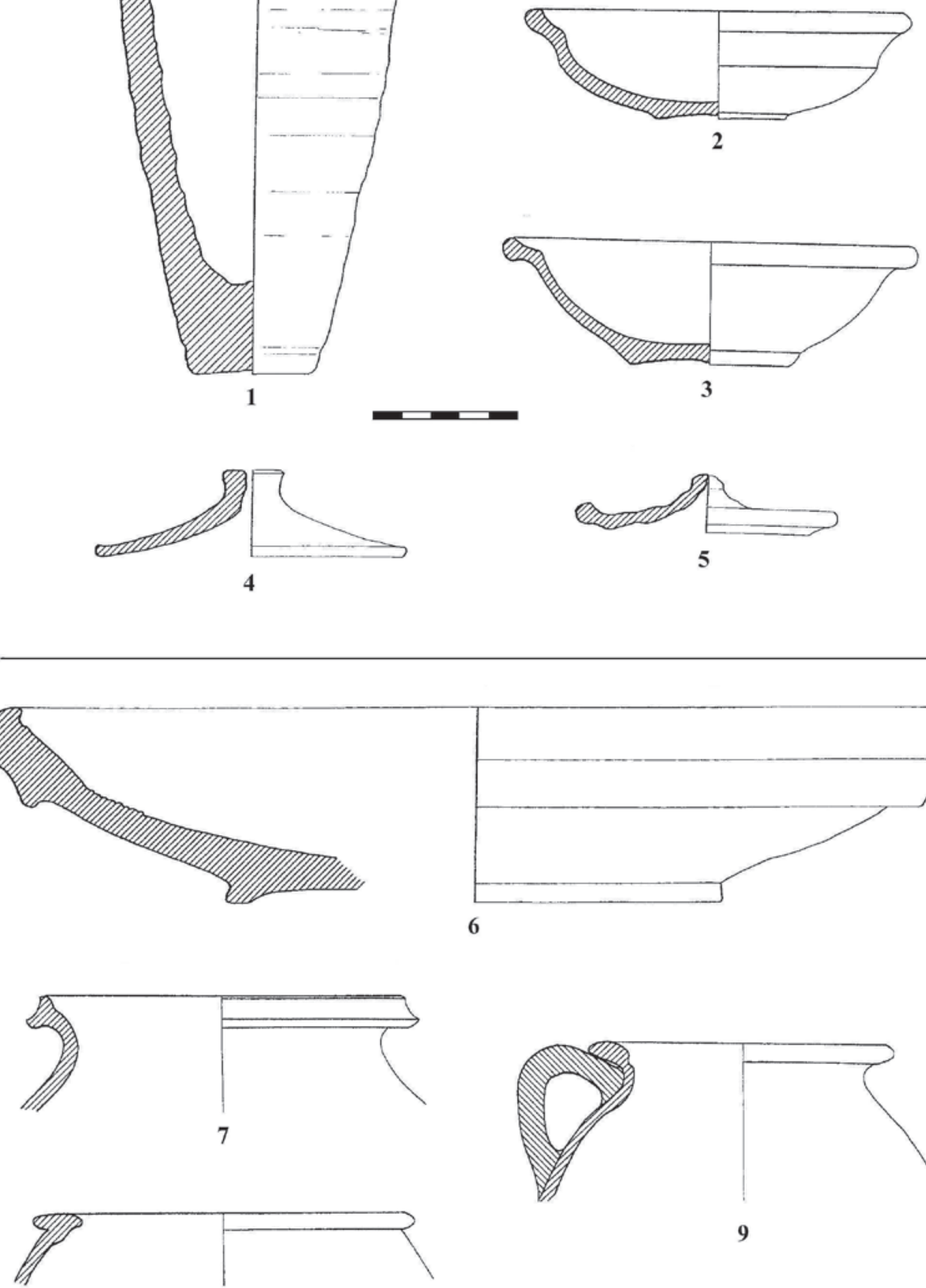


\section{U.E. 11 - FOSA-VERTEDERO}

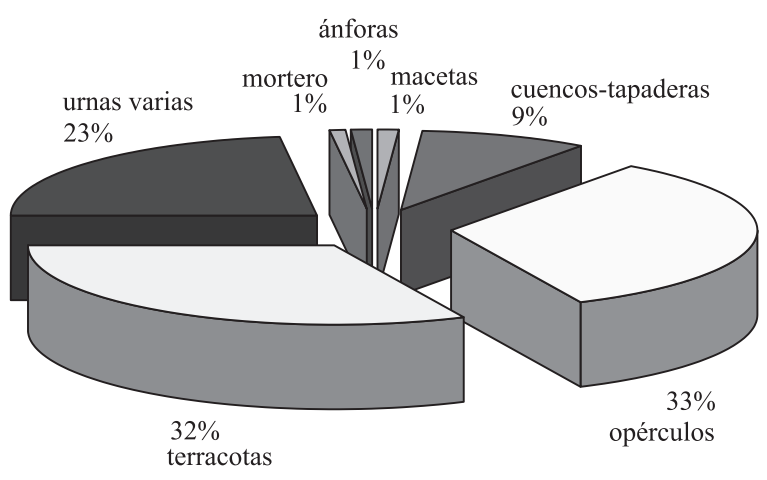

Gráfico 2: Materiales hallados en la fosa adosada al praefurnium (U.E. 11).

(29 fragmentos, 33\%). Estos tipos estaban representados entre el material de la cámara de combustión aunque en número sensiblemente menor respecto a las producciones mayoritarias, por lo que podemos suponer que se trata de formas fabricadas con anterioridad a esta última o últimas hornadas, aunque desde el punto de vista cronológico no advertimos una disparidad destacable, por lo que debieron ser cercanas en el tiempo. Por el contrario, las formas mayoritarias documentadas en el horno, aquí están prácticamente ausentes (sólo se han encontrado dos ejemplares de "cubiletes" y ocho cuencos-tapadera), lo que sería indicativo de que el horno se hundió con la totalidad de las últimas producciones en su interior, y de que los objetos que se cocían en cada hornada eran diferentes a los de la anterior; eso sí, siempre piezas de pequeño tamaño y, como veremos más adelante, relacionadas con la necrópolis y el culto. El resto de los materiales del vertedero se reparte entre distintos tipos de urnas, cazuelas y fuentes de cerámica común romana, destacando la total ausencia de cazuelas de borde bífido, que sí aparecen entre los restos de la cámara de combustión.

Por último queremos señalar que en el interior del praefurnium propiamente dicho no se ha hallado ningún fragmento cerámico diagnosticable, aunque entre las cenizas aparecieron siete fragmentos de mármol, algunos moldurados, de los que desconocemos la procedencia y funcionalidad originales.

\section{III.1. «Pebeteros en forma de cabeza femenina» (Fig. 7; Lám. II)}

Se han hallado cuatro ejemplares bastante completos de este tipo de vasos figurados y algunos fragmentos sin decoración pertenecientes a la parte posterior, kalathos y bases de las figuras ${ }^{11}$. En realidad, un número bastante escaso si tenemos en cuenta que la producción de "cubiletes" y cuencos-tapadera se cuenta por centenares; no obstante, pensamos que existen suficientes argumentos para respaldar que los pebeteros se fabricaron en este horno.

En primer lugar, la mayoría de los ejemplares documentados ${ }^{12}$ proceden de la fosa situada en el acceso al praefurnium, concebida como vertedero y en la que se depositan, como se infiere del nivel de cenizas que presenta, los restos procedentes de la limpieza de la cámara de combustión y los fallos de cocción (Blanco 1999a: 9); documentándose también algún fragmento entre los restos de la cámara de combustión, que indicaría la fabricación de este tipo entre las hornadas anteriores.

En segundo lugar, los pebeteros se fabrican con las dos pastas que caracterizan la producción de vajilla fina gaditana desde momentos púnicos, de color rojo-anaranjado la una y beige-amarillenta la otra, que a continuación se acaban mediante la aplicación de un engobe de las mismas arcillas.

En tercer lugar, algunos ejemplares ( $\mathrm{n}^{\circ} 26.652-\mathrm{Mu}-$ seo de Cádiz-) presentan fallos técnicos, en este caso en la conformación de la cazoleta del kalathos que está deformada, por lo que posiblemente esta pieza fue fabricada en el horno y desechada como no apta para su puesta en circulación.

Y, por último, se ha podido reconocer la existencia de diferentes piezas pertenecientes a un mismo molde, ya que de los cuatro ejemplares casi completos que se conservan dos de ellos se fabricaron a partir de la misma matriz y los dos restantes con otra. Dadas las características particulares de cada conjunto, abiertamente dispares, hemos denominado a los primeros Grupo 1 y a los segundos Grupo 2 (Niveau de Villedary 2007: 169).

En los pebeteros del Grupo $1\left(\mathrm{n}^{\mathrm{o}} 26.651 \mathrm{y} \mathrm{n}^{\circ}\right.$ 26.617 -M.C.-) la figura se representa hasta algo más abajo de los hombros, en contraste con lo que es habitual en el tipo. En líneas generales se encuadran dentro del Tipo IV de Pena (1990: 56): kalathos sin decoración, presencia de aletas laterales, cazoleta superior cerrada; aunque el estilo, muy cuidado, diverge del habitual. El prototipo o modelo reproduce con exquisita

11. Al hallarse muy fragmentados no podemos, salvo contadas excepciones, afirmar categóricamente cuáles de los fragmentos de terracota hallados pertenecerían a formas de pebeteros o si, por el contrario, formarían parte de los askoi figurados que también se fabrican en el horno. En cualquier caso no son más de una docena de fragmentos.

12. Todos excepto un ejemplar ( $n^{\circ} 26.617$-M.C.- $)$ que se halló en una zona próxima muy alterada por una gran fosa de relleno moderno (Blanco 1999a: 17-18) y algunos fragmentos informes recuperados entre los restos de la cámara de combustión. 
A
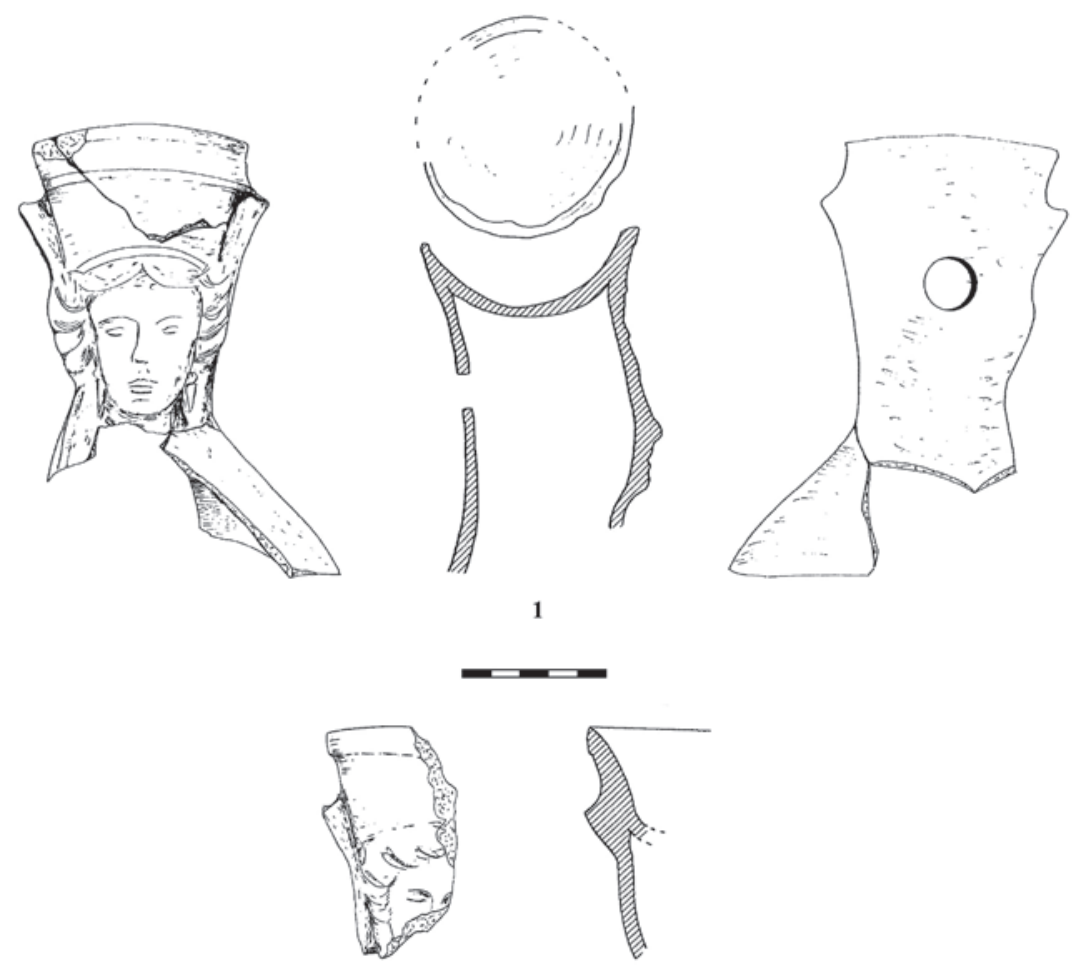

2

B
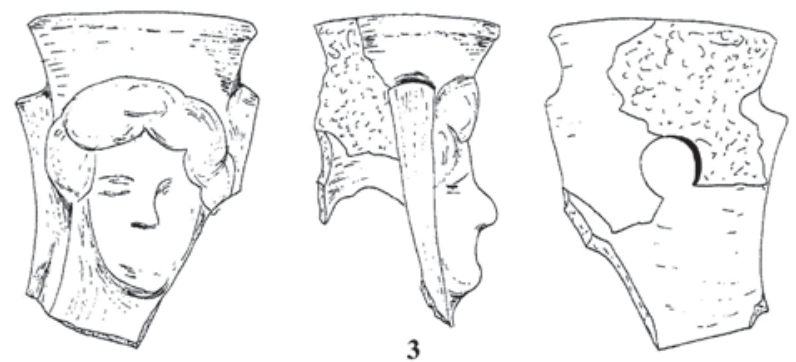
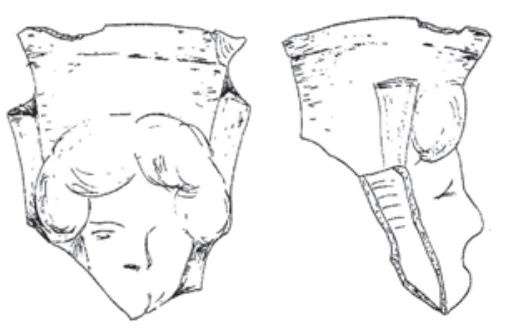

4

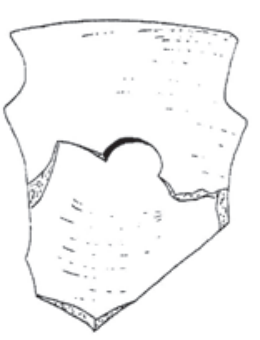

Figura 7: «Pebeteros en forma de cabeza femenina». A. Pebeteros del Grupo 1. 1. N No $^{\circ} 6.651$ (Museo Cádiz). 2. $\mathrm{N}^{\circ} 26.617$ (M.C.). B. Pebeteros del Grupo 2. 3. N 26.650 (M.C.). 4. $\mathrm{N}^{\circ} 26.652$ (M.C.). (Dibujos: Ana $\mathrm{M}^{\mathrm{a}}$ Niveau de Villedary y Mariñas) 

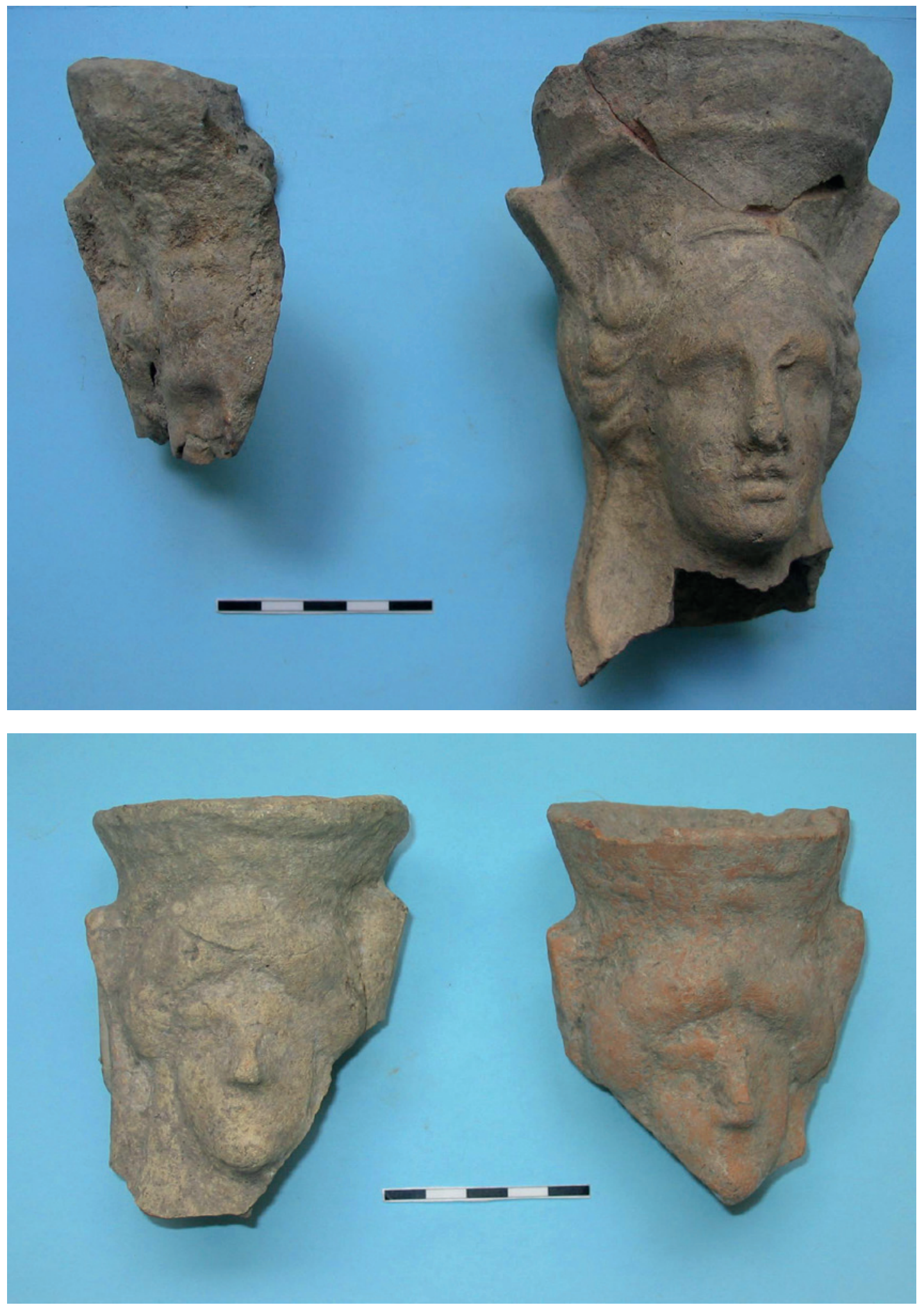

Lámina II: «Pebeteros en forma de cabeza femenina». A. Pebeteros del Grupo 1. B. Pebeteros del Grupo 2. (Fotografías: Ana Ma Niveau de Villedary y Mariñas). 
minuciosidad detalles que se habían perdido en los ejemplares típicos de la primera mitad del s. II a.C.: el peinado detallado, la cinta sobre el cabello, los pendientes de forma lanceolada. También los rasgos faciales son proporcionados y el rostro fino y ovalado; en suma el conjunto resulta armonioso, de notable valor artístico. A semejanza de algunos ejemplares de Cartago, y aunque nunca se llega a las dimensiones de éstos, el kalathos presenta un tamaño mayor que el habitual en las piezas más antiguas, sin embargo las aletas laterales son siempre más reducidas -más cortas y menos desplegadas- que las cartaginesas y las inferiores no se suelen representar.

La principal diferencia entre los dos ejemplares del Grupo 1 radica en que el segundo de ellos ( $n^{\circ} 26.617$ -M.C.-) se fabricó cuando la matriz estaba más gastada, ya que algunos detalles como la cinta sobre el cabello o los pendientes no se advierten y los restantes aparecen desdibujados - mechones de cabello, rasgos faciales-.

Frente a éstas, las dos piezas incluidas en el Grupo 2 (n⿳2 26.650 y n ${ }^{\circ} 26.652$-M.C.-) (Niveau de Villedary 2007: 173), responden a un modelo estilístico bastante desvirtuado (¿evolucionado? ¿producto de artesanos no tan hábiles?), de escaso valor artístico. Esta circunstancia se refleja sobre todo en la representación de los rasgos, que han perdido la armonía -nariz desproporcionada, barbilla prominente, en general aspecto grotesco-, en la eliminación de los detalles secundarios cinta sobre el pelo, pendientes, detalles de los cabellos, que en este tipo parece una burda peluca-y, en general, en el conjunto resultante.

A nuestro entender, estas divergencias se pueden explicar por la posible llegada de artesanos (o moldes) cartagineses a partir del 146 a.C., lo que provocaría una revitalización del tipo en la segunda mitad de la centuria. La irrupción de estos modelos inspiraría a los artesanos locales, no tan diestros (o escasamente motivados por una iconografía que ya "no les decía nada"), que se traduce en la adopción del nuevo modelo, muy desvirtuado y sin solución de continuidad, puesto que no parece que el tipo se extienda más allá de los primeros años del s. I a.C.

\section{III.2. Askoi zoomorfos (Fig. 8; Lám. III)}

Al igual que los pebeteros, la mayor parte de los askoi aparecieron en la fosa junto al praefurnium, aunque también se han recogido algunos fragmentos menores sobre todo pertenecientes a bocas y asas- en la cámara de combustión. Como en el caso de los pebeteros también se pueden diferenciar dos estilos.
La mayoría de las piezas recuperadas responden a los tres tipos clásicos gaditanos definidos por Ángel Muñoz, que son frecuentes en los contextos funerarios (Muñoz 1992: 7-8) e industriales (Bernal et alii 2003: fig. 20, 5 y 6; fig. 25, 6; fig. 30, 10-11; Montero et alii 2004: fig. 2) de los ss. II-I a.C.

Los dos ejemplares más completos $\left(\mathrm{n}^{\circ} 26.654\right.$ y $\mathrm{n}^{\mathrm{o}}$ 26.655 -M.C.-) pertenecen al Tipo A, askos en forma de paloma con dos bocas y un asa, cuerpo piriforme cuya parte inferior le sirve de apoyo y frente circular plano (Muñoz 1992: 7; fig. 1, 1-2); aunque ninguno de los dos presenta decoración pintada, posiblemente porque se desechan nada más salidos del horno. Del Tipo A se han recuperado también algunas cabezas y colas de forma abierta (Muñoz 1992: fig. 1, 2).

El Tipo B, askos en forma de gallina o gallo, con dos bocas, asa sobre el cuerpo y base circular plana (Muñoz 1992: 7; fig. 1, 3-4), está representado por una cabeza con cresta desarrollada y pico-vertedor fracturado y del $\mathrm{C}$, representación aviforme esquemática e indefinida, con asa sobre el cuerpo y dos bocas, una de las cuales es un largo pitorro (Muñoz 1992: 7; fig. 1, 5-6), se han individualizado varios fragmentos de estos últimos.

Junto a los tipos clásicos descritos, apareció un askos casi completo ( $\mathrm{n}^{\circ} 26.653-$ M.C.-) al que sólo le falta la cabeza y parte de la cola, que representa con un estilo realista que podríamos calificar de "helenístico" un ga1lo. El vaso se sostiene mediante un pie alto, a modo de peana, donde se reproducen las patas del animal con todos su detalles. A partir de éste se abre el cuerpo de la vasija, de forma globular, que corresponde al cuerpo del ave, destacando el realismo con que se representan las alas y el resto del plumaje. En la parte superior, entre la cola abierta y uno de los extremos del asa, se coloca una de las bocas del jarro, mientras que la otra - de la que parte el asa pequeña y geminada- mediante la cual se vertería el contenido y que debía representar la cabeza del gallo, no se ha conservado.

Esta pieza, en principio excepcional por cuanto que no se conocen paralelos en la necrópolis gaditana, no debió ser única si tenemos en cuenta la presencia de algunos fragmentos de pequeño tamaño que presentan decoraciones de plumajes similares en este mismo contexto.

Como en el caso de los pebeteros, la irrupción de esta forma en el panorama funerario gaditano a partir del s. II a.C. se ha explicado por la llegada de elementos cartagineses a partir de mediados de siglo tras la destrucción definitiva de Cartago (Montero et alii 2004: 422-423), puesto que se trata de una forma inédita en la necrópolis gaditana hasta ese momento y, por el contrario, sí están bien atestiguados en Cartago y otras zonas del mundo púnico centromediterráneo (Muñoz 1992: 8). 


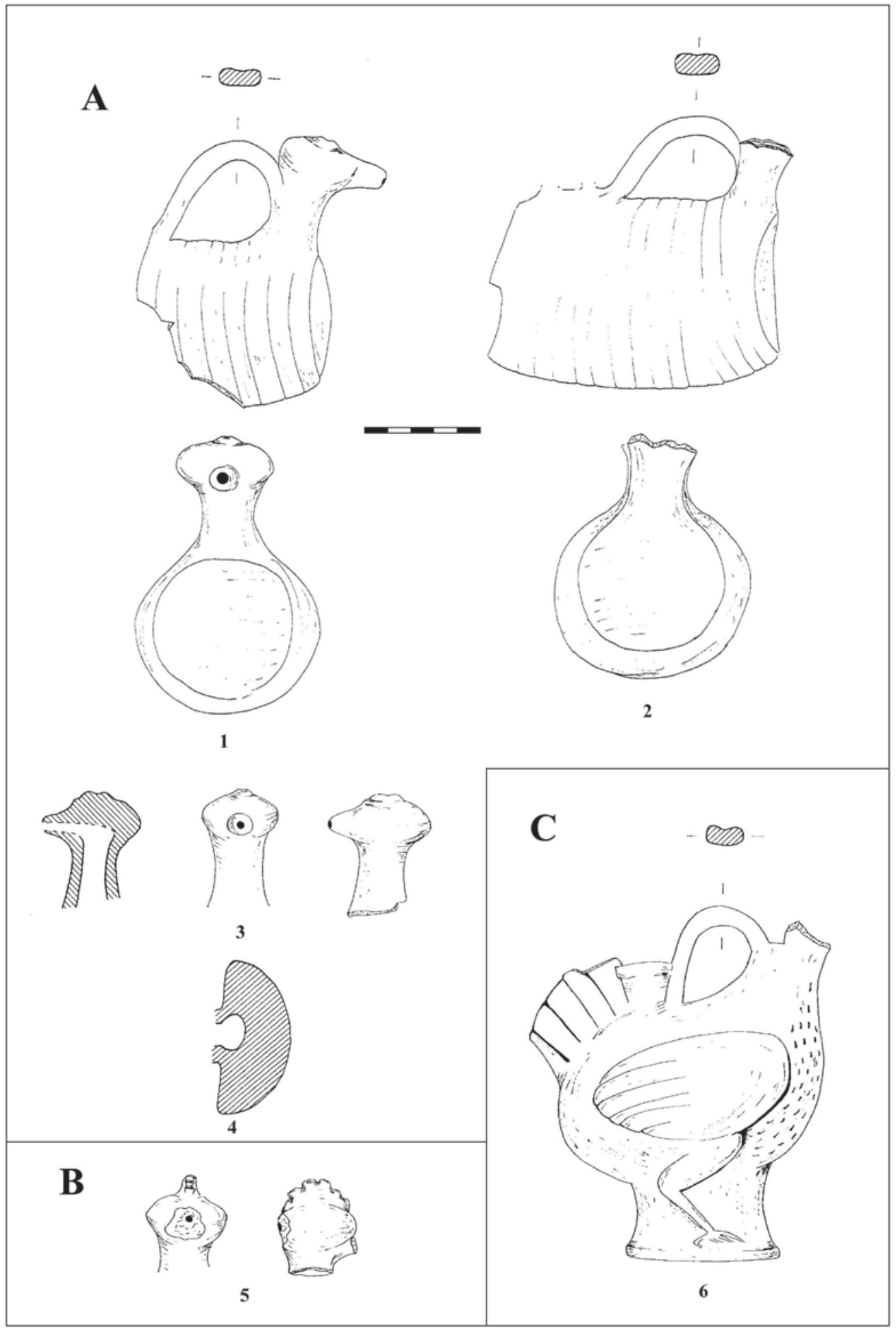

Figura 8: Askoi zoomorfos. A. Tipo Muñoz A. 1. No 26.654 (M.C.). 2. $\mathrm{N}^{\circ} 26.655$ (M.C.). 3-4. № 26.656 (M.C.). B. Tipo Muñoz B. 5. No 26.656 (M.C.). C. Askos de estilo "realista". 6. No 26.653 (M.C.). (Dibujos: Ana $\mathrm{M}^{\mathrm{a}}$ Niveau de Villedary y Mariñas). 


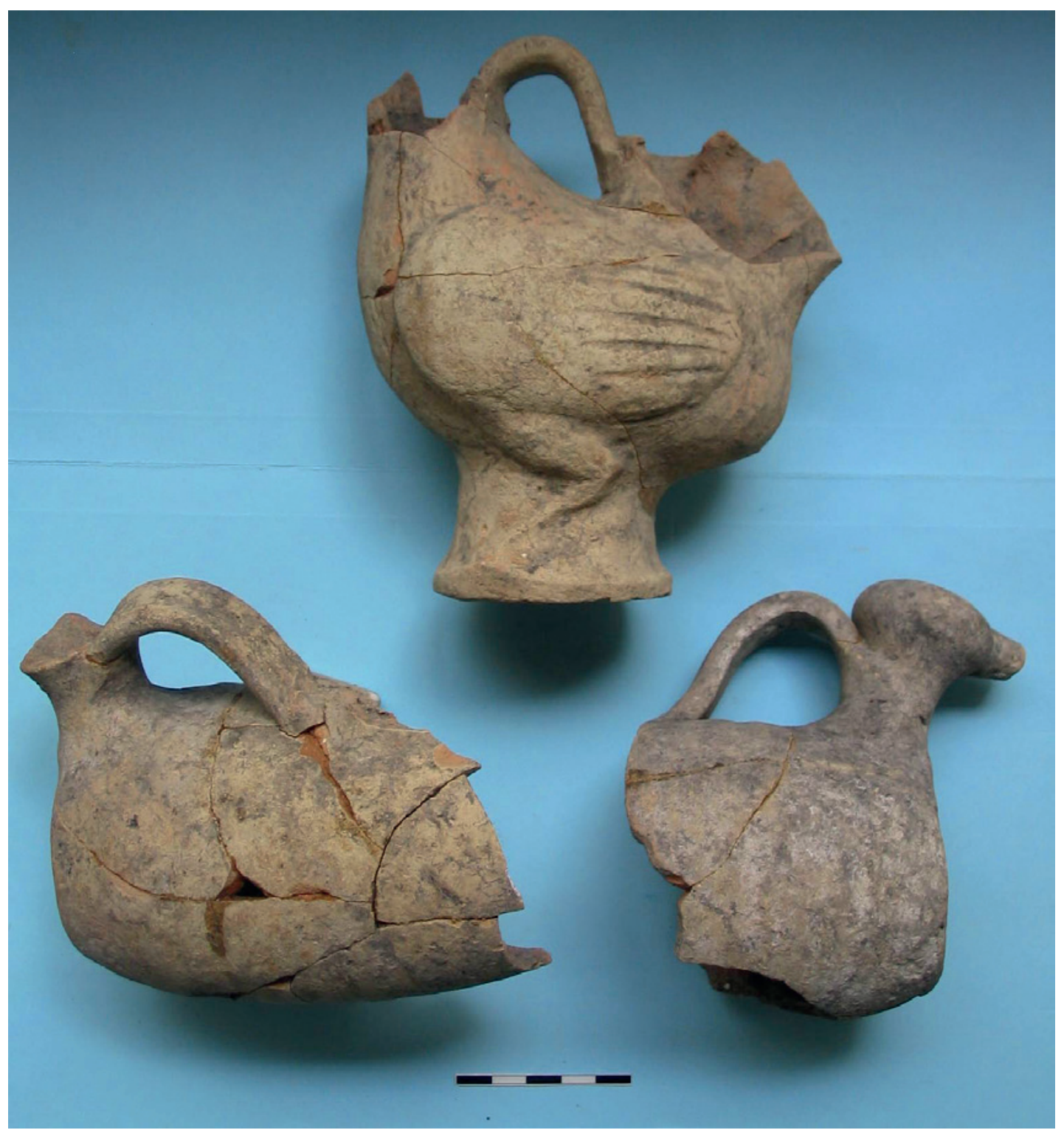

Lámina III: Askoi zoomorfos. (Fotografías: Ana Mª Niveau de Villedary y Mariñas).

\section{III.3. Vajilla fina republicana}

Por la presencia de los tipos descritos -"pebeteros en forma de cabeza femenina", iconografía tardopúnica que se desarrolla entre los siglos IV y II a.C., y askoi zoomorfos, que caracterizan la facies de la segunda centuria en la necrópolis gaditana- hay que pensar que nos encontramos ante un taller de cronología y raigambre "púnica" o "tardopúnica"; ahora bien, el resto de los vasos fabricados evidencian que en el horno ya se están produciendo formas de la cerámica fina romana ${ }^{13}$, algunas de filiación local, pero otras tipologías -como las cazuelas de borde bífido- a imagen de las producciones itálicas. Eso sí, creemos que en un ambiente cultural que todavía puede considerarse fundamentalmente púnico.

13. Agradecemos desde estas líneas a Lázaro Lagóstena sus apreciaciones y comentarios sobre el repertorio vascular asociado a la estructura de combustión que presentamos. 
III.3.1. Producciones mayoritarias: cuencostapaderas y "cubiletes"

Los tipos más representados son los que proceden del interior de la cámara de combustión y que, por tanto, se corresponden con la última o últimas hornadas. En términos generales se reducen a dos formas: los cuencos tapadera y los "cubiletes".

Los cuencos-tapadera con escalón son del tipo que en Cádiz cubren las urnas cinerarias hasta época JulioClaudia (Sáenz y Perdigones 1991: fig. 3; Gener 1999: fig. 1; López de la Orden 2003: 113; fig. 4, 15) (Fig. 9).

Existen numerosas variantes aunque siempre responden a un perfil común. En general, presentan forma de cuenco hemisférico, de líneas suaves y continuas (Fig. 4, 2-3 y Fig. 6, 3), si bien en ocasiones la pared se quiebra en el tercio superior, originándose un tenue perfil en "S" y una leve carena al exterior (Fig. 6). Menos frecuentes son aquellas piezas más amplias y menos profundas, de perfiles cercanos a los "platos". Los fondos son anulares, simples, apenas señalados al exterior y levemente rehundidos en la zona de apoyo, a veces con un ligero umbo interno, externo o en ambas superficies. La línea del cuerpo se vuelve al exterior más o menos bruscamente para formar el labio, que aunque presenta perfiles muy variados (horizontales, más verticales, suaves o angulosos, surcados por acanaladuras) siempre son engrosados, lo que funcionalmente permite que se apoyen en la boca de las urnas que cierran. A su vez, el escalón que tienen los bordes en su cara superior permitiría el hipotético apoyo de tapaderas sobre ellos (¿quizás mediante morfologías análogas?).

Las dimensiones son bastante constantes, aunque presentan algunas variaciones. Los diámetros de las bocas (que coincide con el diámetro máximo de la pieza) oscila entre los 13-15 cm. para el caso de los cuencos y algo mayores, en torno a los $20 \mathrm{~cm}$., para las formas de plato. Las medidas de las bases están entre los $4 \mathrm{~cm}$. y medio y los $6 \mathrm{~cm}$. y medio; mientras que las alturas son más constantes entre los $4 \mathrm{~cm}$. $-4 \mathrm{~cm}$. y medio. Esta uniformidad no debe sorprendernos si tenemos en cuenta que estamos hablando de vasos pertenecientes a las mismas series cerámicas. Las escasas variaciones en la talla y en ciertos detalles morfológicos vienen dadas, como intentaremos demostrar a lo largo del trabajo, por el carácter artesano de la producción de este taller.

En cuanto a la segunda de las formas, que hemos denominado "cubiletes", se trata de piezas cerámicas de forma troncopiramidal que se estrechan por la base, con paredes gruesas, bordes rectos y redondeados y factura grosera. Conservan tanto en su cara interna como en la externa las huellas del torneado, normalmente de forma

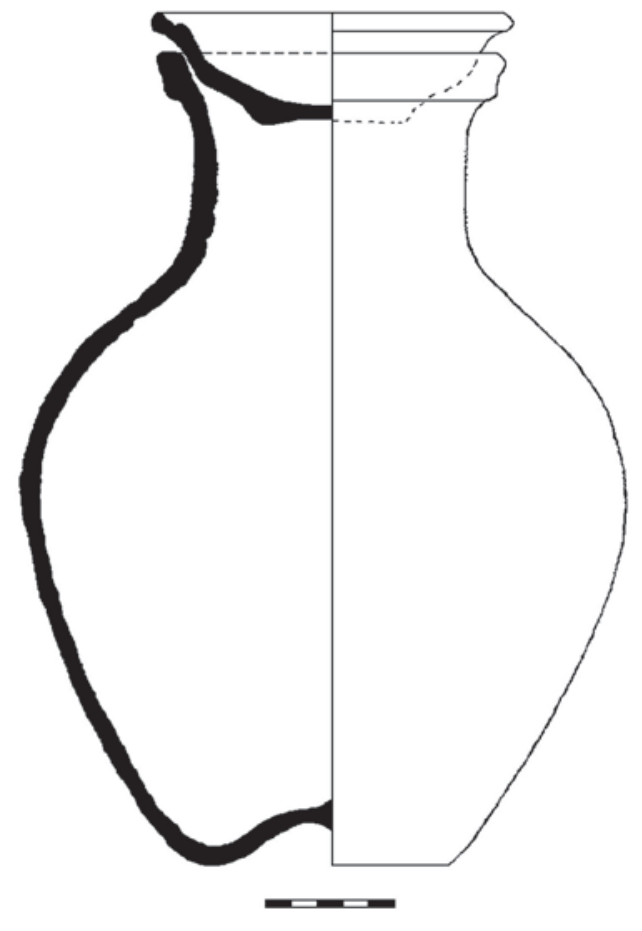

Figura 9: Urna cineraria cubierta mediante un cuenco-tapadera del tipo fabricado en el horno de Troilo. (Dibujo: Ana $\mathrm{M}^{\mathrm{a}}$ Niveau de Villedary y Mariñas, en López de la Orden 2003: fig. 4,15$)$.

evidente, lo que nos lleva a pensar que se trataba de recipientes poco cuidados que en ningún caso pueden incluirse dentro de la vajilla fina.

Las dimensiones son muy constantes, de hecho la variación es mínima. Los diámetros de las bocas se encuentran en torno a los $9 \mathrm{~cm}$. y medio $-10 \mathrm{~cm}$., las bases alrededor de $4 \mathrm{~cm}$. y las alturas entre los $15 \mathrm{y}$ los $16 \mathrm{~cm}$. Las paredes presentan un espesor de $c a$. $1 \mathrm{~cm}$., mientras que el grosor de la base varía desde el centímetro hasta alcanzar en ocasiones cerca de $4 \mathrm{~cm}$.; sin embargo nunca aparecen horadados.

El principal problema que plantean estas piezas es el de su funcionalidad. No se trata de una producción esporádica puesto que se han documentado en talleres cercanos, en el mismo casco urbano de Cádiz ${ }^{14}$ y en

14. Producciones similares aparecieron en la excavación del solar ubicado en la C/ Santa María del Mar e/ Santa Cruz de Tenerife, en las cercanías de la necrópolis fenicio-púnica. Información personal de su excavadora Maribel Molina Carrión. 
la campiña jerezana (García Jiménez, Zuleta y Prieto 2004: 666, fig. 11). Se ha propuesto que fuesen "macetas", pero su reducido tamaño - ya que la capacidad real de los recipientes es mínima- y la ausencia de orificios en las bases, en principio, contradicen tal hipótesis. Generalmente, se han interpretado como "macetas" los recipientes de morfologías similares a los lebrillos (formas anchas y bajas), pero con los fondos horadados. Esta última característica, el orificio inferior, impediría la utilización de los recipientes en las labores propias de los labella, para el lavado a pequeñas escala o como recipiente auxiliar en las tareas domésticas; y, sin embargo, los haría aptos para criar plantas (Chic 1984: 278). La costumbre del exorno mediante plantas debió ser habitual en el mundo romano como parece desprenderse de algunos hallazgos arqueológicos en Pompeya y Roma y del testimonio de poetas como Marcial y Juvenal (Chic 1984: 279-280). Un caso concreto del uso de macetas y plantas son las fiestas celebradas en honor de Adonis. Entre otros ritos, durante las Adonías las fieles ofertaban al dios “minúsculos jardines de vida efímera" cultivados en cualquier tipo de recipiente: macetas, cestos e incluso fragmentos de cerámica o ánforas (Belén, Conlin y Anglada 2001: 151). En la necrópolis de Cádiz se documentan con mucha frecuencia cuerpos de ánforas clavados en el terreno, casi siempre formando alineaciones y, al parecer, delimitando zonas (Niveau de Villedary 2001: 192), aunque se ha señalado también esta posible función decorativa, como tiestos para plantas (Blanco 1999b: 26).

Otra posible explicación es que nos encontremos ante cangilones de noria. La escasa uniformidad de las paredes exteriores, con líneas y surcos del torno, permitirían la sujeción de los recipientes por medio de cuerdas a la rueda hidráulica (Benabat y Pérez Macías 1999: 236); sin embargo, la escasa capacidad de las vasijas, así como el grosor de las paredes parecen descartar esta hipótesis ${ }^{15}$.

Finalmente, se ha especulado conque se utilizaran como tapones de ánforas. Aunque no es frecuente que los envases lleguen a nosotros cerrados, tenemos constancia de la utilización de diversos sistemas de cierre desde época prerromana bien a base de pellas de arcilla cruda envueltas con hojas o tela o bien de arcilla cocida, sellada con resina, tiras de arcilla cruda, cuñas, etc. (Rodero 1995: 136). Incluso se admite que los

15. La documentación procedente de una noria hispano-musulmana de la provincia de Huelva muestra recipientes de paredes sutiles, con mayor capacidad, de perfiles cilíndricos o globulares y con dos escotaduras - una inferior y otra superior-que permiten el amarre de la vasija. Cf. Benabat y Pérez Macías 1999: 236, figs. 1-4. fondos cónicos de las ánforas, dispuestos en hileras superpuestas, fueran los que sellaran los envases de las filas inferiores (Rodero 1995: 137); lo que a su vez permite suponer que se utilizaran bases amortizadas como tapones o que incluso se llegaran a manufacturar elementos similares con tal fin. Éste podría ser el caso de los vasos fabricados en el horno de Troilo, tanto más cuanto también se están produciendo otras morfologías -opercula- que en este caso sí estamos seguros que se utilizaron para cerrar las ánforas.

\section{III.3.2. Otros materiales: opérculos, cazuelas de borde bífido, fuentes, urnas, morteros}

La producción del horno debió variar en cada hornada (o serie de hornadas). Si la última no cabe duda de que estuvo compuesta en su totalidad por los cuencos-tapadera y los “cubiletes" que colmatan la cámara de combustión, en las anteriores tenemos documentadas otra serie de elementos, con una representación variable.

En primer lugar, por el número de ejemplares destacan las tapaderas de pequeño tamaño que conocemos por opérculos. Si tenemos en cuenta que se trata de la forma más representada en el vertedero (33\%) (Fig. 4, 4) y la tercera en la cámara del horno (aunque únicamente con un $3 \%$, es decir un porcentaje prácticamente insignificante) (Fig. 6, 5) debemos suponer que sería uno de los tipos que se cocieron en las hornadas inmediatamente anteriores. Se corresponden con la Forma 62 de la clasificación de Mercedes Vegas (1973: 149, fig. 57) y con el Tipo 4 de la más reciente de Gloria Olcese (2003: 90-91, lám. XX). Son formas circulares y bastante planas, con bordes simples vueltos ligeramente hacia arriba que terminan en un pequeño pomo o pellizco central, aunque a veces carecen de él. En este contexto advertimos la fabricación de la forma en dos tallas: una mayor en torno a los 11-12 cm. de diámetro máximo y otra algo menor, sobre los $8-9 \mathrm{~cm}$. Las alturas oscilan entre los 2-3 cm. Como en otros hallazgos procedentes de alfares de la ciudad de Cádiz, la mayor parte de las piezas presentan un orificio central que atraviesa el pomo (Fig. 4, 4) y que, al parecer, debió servir para introducir un cordoncillo que facilitara su extracción (Bernal et alii 2004a: 630). Funcionalmente se utilizaron como tapaderas de ánforas u otros contenedores. Las de menor tamaño debieron servir para cubrir olpes, jarras y anforiscos en ambientes domésticos. Se trata de una forma no documentada con anterioridad al 200 a.C., cuya aparición se asocia a innovaciones difundidas por los romanos y que hay que relacionar con la producción de nuevas formas anfóricas, por una parte imitaciones 
itálicas (grecoitálicas primero y Dressel 1 a continuación) a pequeña escala $\mathrm{y}$, por otra, la fabricación masiva de T-7.4.3.3. de filiación púnico-cartaginesa y que en este contexto histórico se ha interpretado como una "licencia productiva" que Roma permite a los gaditanos (Bernal et alii 2004a: 630). En un par de casos se ha documentado la presencia de tapaderas de botón central una de ellas con orificio central (Fig. 6, 4)-, aunque al tratarse de ejemplares aislados hallados fuera de la cámara de cocción no podemos afirmar con rotundidad si la forma se fabricó o no en el horno.

El siguiente tipo más representado en la cámara de cocción del horno son las cazuelas de borde bífido (Fig. $4,5)$, de las que se contabilizan 27 ejemplares; estando la forma, a su vez, totalmente ausente en la fosa-vertedero aneja, por lo que podría tratarse de un tipo fabricado exclusivamente en la última hornada o con más probabilidades en algunas de las inmediatamente anteriores. Tradicionalmente se engloban en la forma 14 de Vegas (1973: 43-45, fig. 15)/Nouaesium 18 (Beltrán 1990: 201, fig. 99). Son tipos de fabricación itálica muy común en épocas tardo-republicana y augústea cuyo su empleo se extiende por todo el Mediterráneo. En general, se trata de grandes platos o fuentes de cocina, con base plana y paredes ligeramente curvas, cuyo borde liso está dividido en su parte superior por una estría más o menos profunda que, funcionalmente, sirve para apoyar una tapadera. Es una forma realizada con arcillas campanas, aunque seguramente también se produjeron en el Lazio (Olcese 2003: 27), en tonalidades marrón-rojizo, con bastante cuarzo y mica como desgrasante (Vegas 1973: 43). Los ejemplares documentados en el horno gaditano se ajustan a la variante Vegas 14A (1973: 45; fig. 15, 4) que aparece sobre todo en la Bética y en la que la estría que separa el borde ha desaparecido. Éste, no obstante, sigue dividido en dos partes, la interior más baja que la exterior, de manera que se origina una pequeña superficie para asiento de la tapadera. En general, son de menor tamaño que la forma original, en nuestro caso en torno a los 15$16 \mathrm{~cm}$. de diámetro máximo, que se corresponde con la boca, 10-12 cm. de diámetro de las bases y unos 4 $\mathrm{cm}$. de altura. En un principio se dataron en el s. I d.C. (Vegas 1973: 45), aunque con posterioridad se documentó un uso profuso en Hispania desde al menos la primera centuria antes de la era (Beltrán 1990: 201) o un poco antes (Serrano 2000: 17). En la actualidad, se considera que en la península itálica su fabricación comienza hacia finales del s. IV y, sobre todo, el s. III a.C. (Olcese 2003: 85), tratándose de una forma típica de la segunda mitad del s. II a.C., en especial entre el 130 y el 90 a.C. (Aquilué, García Roselló y Guitart 2000:
392-393), posiblemente difundida por las tropas romanas, ya que formaban parte de los impedimenta de los soldados. Las recientes excavaciones en los alfares de Pery Junquera han constatado la producción local de esta forma, en principio itálica, en los alfares del sur de la península Ibérica (Niveau de Villedary 2004b: 686).

El resto de materiales hallados en el relleno de las estructuras, salvo las terracotas, no deben ser vasos fabricados en el horno por su escasa representación. En algunos casos responden a objetos depositados consciente o casualmente en el vertedero, en otras se trata de elementos que forman parte de los diferentes estratos de sedimentación.

Entre los materiales hallados en la cámara del horno ${ }^{16}$ destaca la presencia de una cazuela completa de tamaño considerable $(27 \mathrm{~cm}$. de boca, $20 \mathrm{~cm}$. y medio de fondo y $6 \mathrm{~cm}$. de altura) (Fig. 4,6), que se puede incluir entre las "cazuelas con asa" descritas para las producciones antequeranas (Serrano 1997: 221, fig. 16), aunque en este caso estamos hablando de productos algo más tardíos, en torno a la segunda mitad del s. I y s. II d.C. La forma se caracteriza por presentar un borde redondeado y acanalado para asiento de la tapadera, asas semicirculares bajo éste y diámetros que oscilan, en los ejemplares malagueños, entre los 28 y los $34 \mathrm{~cm}$. Por las características técnicas, la forma general y las dimensiones se ha propuesto una utilidad relacionada con la cocina. Formas similares, aunque con algunos matices, se fabrican en los alfares de la Fábrica, Campillos, Mérida, Cartuja y Torrox (Serrano 1997: 221).

Lógicamente, la variedad tipológica es mayor entre el relleno de la fosa vertedero, de donde proceden un buen número de fragmentos de urnas, jarras y otras formas cerradas, algunas de tradición púnica como las de borde triangular (Fig. 6,7) y otras morfologías plenamente romanas como las cazuelas de borde horizontal (Fig. 6, 8), el caccabus de las fuentes clásicas (Serrano 2000: 14-15, figs. 2-8).

Por último, destacamos la existencia de un mortero prácticamente completo (Fig. 6,6), en el que se conjugan elementos morfológicos tradicionales púnicos con otros novedosos, típicos de los ejemplares republicanos, como es la sustitución de las piedras del fondo por acanaladuras, rasgo que es característico, sobre todo, entre las producciones béticas (Serrano 1997: 221). En donde más varían los morteros locales respecto a los originales itálicos es el perfil de los bordes. En el caso que nos ocupa el vaso carece del característico labio colgante utilizado para asir el recipiente, aunque en la unión entre

16. En el caso de la cámara de cocción del horno (U.E. 8) estas otras piezas apenas suponen el $2 \%$ de total de materiales contabilizados. 
el borde, engrosado respecto a las paredes, y el cuerpo se produce una ligera concavidad que sirve para este fin. La pieza apareció con la superficie totalmente ennegrecida y con restos de cenizas en su interior.

En suma, el conjunto representa una facies típica de cerámica común romano-republicana característica de los siglos II-I a.C., con las particularidades de la zona gaditana, suma de las pervivencias púnicas y del carácter más dinámico de las producciones de las zonas costeras (Baldomero et alii 1997: 155).

\section{CRONOLOGÍA Y FUNCIONALIDAD.}

Una vez descrito el horno y los materiales asociados a él son dos las cuestiones que se nos plantean. En primer lugar la cronología de uso y de colmatación de la estructura de combustión y la fosa adyacente y en segundo término el destino final de la producción de este pequeño alfar de carácter suburbano.

\section{IV.1. Las bases de la cronología. La fase de uso y la estratigrafía de colmatación: el material anfórico, numismático y vascular}

De acuerdo a los paralelos isleños descritos la estructura debería fecharse como muy tarde a caballo entre los siglos III y II a.C., puesto que se ha considerado que se trata de una innovación púnica que no perdura en momentos romanos. Ahora bien, a esta afirmación le podemos hacer, al menos en lo que respecta a este caso concreto, una serie de precisiones que nos permiten alargar algo más la cronología de la estructura gaditana.

Hay que partir de la base que es necesario distinguir al menos tres fases cronológicas: una primera sería el momento de construcción del horno, otra que vendría dada por el periodo de uso del mismo y una última caracterizada por su abandono, diferenciando a su vez entre el abandono propiamente dicho y la amortización final de la estructura. No sabemos a falta de elementos diagnósticos fiables en qué momento concreto se construyó el horno, aunque por una serie de indicios podemos suponer que fue bien entrado ya el s. II a.C. En primer lugar por la tendencia cuadrangular de la cámara, novedad morfológica introducida por los romanos, que no se utiliza en el mundo púnico. Otra razón sería la ausencia total de cerámica púnica $y$, por el contrario, la presencia y fabricación de tipos republicanos característicos que permiten suponer una construcción ex novo del complejo industrial.

Si bien no es fácil precisar con exactitud el momento en que empieza a funcionar esta estructura podemos asegurar, por la tipología de los materiales hallados en su interior, que estuvo en funcionamiento durante buena parte de la segunda mitad del s. II a.C. A pesar de la ausencia de vasos de barniz negro, de T.S. y de envases anfóricos, elementos diagnósticos por excelencia, contamos con otros materiales que nos ofrecen una información cronológica relativamente fiable. Por una parte, tanto los askoi aviformes como los "pebeteros en forma de cabeza femenina" son tipologías funerario-cultuales desconocidas hasta el momento, que se introducen por parte de los cartagineses o por influencias cartaginesas hacia mediados del s. II a.C. tras la destrucción de la metrópolis centroafricana y que posiblemente perduren hasta un momento avanzado del s. I a.C. (Montero et alii 2004: 422-423). También es a partir del s. II cuando se pueden fechar los opérculos, que no se fabrican hasta esa fecha en los alfares púnicos (Bernal et alii 2004a: 630). Incluso en Cartago no son nunca anteriores al 200 a.C. (Adroher 1993: 378). Las cazuelas de borde bífido nos indican asimismo contextos de la segunda mitad de la segunda centuria antes de la era. Por tanto, la mayoría de los materiales depositados en la fosa vertedero, que interpretamos como desechos de hornadas anteriores (opérculos y terracotas), apuntan como término post quem para el inicio del funcionamiento del horno la segunda mitad del s. II a.C.; morfologías que hallamos también, aunque de forma residual, en la cámara del horno. A su vez, los materiales que colmatan ésta (que salvo intrusiones aisladas no aparecen en el relleno del vertedero): cuencos-tapadera y "cubiletes", que constituyen la última hornada producida en la estructura, cronológicamente pueden prolongarse hasta un momento algo posterior, quizás entre finales del s. II y comienzos del I a.C., puesto que el uso de cuencos-tapadera está atestiguado en la necrópolis de Cádiz hasta una fecha tan tardía como es la época Julio-Claudia (VV.AA. 2002: 50, fig. 5). El término ante quem viene dado por la aparición de una unidad de la Serie VI de Alfaro (1988: 81-84) de la ceca gaditana en los primeros niveles que cubren el derrumbe del horno, que nos da una fecha aproximada en torno a la segunda mitad del s. I a.C. (Blanco 1999a: 11).

El siguiente referente cronológico fiable lo encontramos en un conjunto de ánforas (Fig. 10) asociado al nivel de construcción del muro que atraviesa longitudinalmente el horno, que se levanta una vez inutilizado éste, aunque no podemos saber el tiempo transcurrido entre un hecho y otro. Este muro, realizado a base de sillares y sillarejo de piedra ostionera local, podría relacionarse con la cimentación de una posible vivienda supuestamente perteneciente a la construcción de la Neápolis de Balbo el Menor a mediados del s. I a.C. (Blanco 1999a: 15), que entrañaría la reconversión 
de esta zona periurbana de uso industrial en el centro público de la nueva ciudad ${ }^{17}$. Las ánforas aparecieron en contacto con la capa compacta de tierra arcillosa de greda verdosa-amarillenta con inclusiones calizas que forma el propio firme natural del terreno (U.E. 5), base del muro posterior. El conjunto ${ }^{18}$, compuesto casi exclusivamente por ánforas vinarias de tipología itálica o de influencia itálica (Haltern 70 antiguas, Dressel 2/4 y ovoide gaditana), se fecha en torno a la mitad del s. I a.C., si no antes. Llama la atención la completa ausencia de ánforas salsarias tardopúnicas junto a este material, sobre todo en comparación con lo que sucede en el ager gaditano en las mismas fechas.

El último dato cronológico lo ofrece un segundo conjunto de ánforas (Fig. 11) procedente en este caso de los niveles superiores de relleno del horno, tanto de la cámara (U.E. 8) como de la fosa adosada al praefurnium (U.E. 11) y que fechan la colmatación definitiva de la estructura, que debió ser lenta, en época augústea (s. I d.C.). En esta ocasión predominan las formas salsarias (Dressel 7/11, Dressel 12, Beltrán IIB) sobre las vinarias (Haltern 70 augústeas).

En definitiva, los datos cronológicos nos llevan a proponer como fecha de funcionamiento de la estructura el periodo comprendido entre la segunda mitad del s. II a.C. y los primeros años de la siguiente centuria, lo que prolongaría el periodo de uso de estas tipologías industriales o al menos de ésta en concreto, toda vez que en estos momentos e incluso un poco antes, ya se están introduciendo novedades tecnológicas en alfarerías cercanas, como es el caso de Avda. de Portugal (Bernal et alii 2004a). Consideramos, pues, que el horno de Troilo constituiría una pervivencia residual de estas estructuras de combustión tardopúnicas características de un momento algo anterior.

\section{IV.2. El horno de la Calle Troilo ¿Un ejemplo de alfar al servicio de la necrópolis y el culto?}

Nos hallamos ante un horno alfarero de dimensiones modestas, que no sabemos en principio si forma parte o no de un complejo industrial de mayor alcance, aunque no hay evidencias de ello en las inmediaciones (otras estructuras de combustión o testares).

Este horno, que hemos propuesto que estaría en funcionamiento durante la segunda mitad del s. II a.C.

17. Recordemos que la zona ocupada por el horno se halla muy próxima a importantes edificios públicos como el Anfiteatro.

18. Queremos agradecer a Enrique García Vargas sus apreciaciones sobre la tipología y cronología de las ánforas halladas. y quizás en la primera parte de la siguiente centuria, estaba destinado a la fabricación de piezas de pequeño tamaño de cerámica común y objetos de terracota votivoreligiosos. Se trata de una especialización productiva ampliamente constatada en la industria alfarera púnica de San Fernando desde las primeras intervenciones llevadas a cabo en Torre Alta. En numerosas ocasiones se ha comprobado que en un mismo complejo conviven hornos de tamaño mayor destinados a la fabricación de envases anfóricos, con otros más pequeños en los que se fabrican piezas menores de la vajilla de mesa o, como en este caso, objetos votivos (Frutos y Muñoz 1994: 398; Gago et alii 2000: 46; Sáez Romero et alii 2004:109).

Ahora bien, pese a las similitudes que el horno de Troilo presenta con los alfares isleños es necesario hacer una serie de puntualizaciones cronológicas, geográficas y funcionales. Hay que tener en cuenta que mientras que los segundos son el resultado final -desde el punto de vista cronológico- de una tradición alfarera muy intensa, implantada desde hace siglos, la estructura gaditana a primera vista responde más bien a una actividad puntual que surge ex novo, con una función específica y más concreta, frente al carácter "industrial" a gran escala de la producción alfarera de la tercera isla gaditana en época fenicio-púnica. Nos encontramos, por tanto, ante un pequeño taller de carácter suburbano, de tradición púnica en cuanto a su tipología, pero en funcionamiento durante los siglos II-I a.C. como denota el repertorio vascular fabricado en él que salvo las terracotas, de influencia cartaginesa, son formas de la cerámica común romana.

El análisis de los tipos cerámicos fabricados nos lleva a proponer que nos encontramos ante un horno dedicado en gran parte a surtir de ciertos productos a la cercana necrópolis. No existen dudas respecto al destino de ciertas categorías vasculares como los askoi zoomorfos, los "pebeteros en forma de cabeza femenina" o los cuencos-tapaderas que se utilizan como cubiertas de las urnas funerarias; formas que por otra parte constituyen el grueso de la producción. Otras, como los "cubiletes", las cazuelas de borde bífido o los opérculos, en principio, no parece que tengan un fin funerario. Los opérculos se utilizan fundamentalmente para sellar las ánforas -se ha propuesto que surjan en relación con las T-7.4.3.3. (Bernal et alii 2004a: 630)-, la misma función que hemos sugerido para los "cubiletes". Por tanto, si la fabricación en el horno de elementos de cierre destinados a envases anfóricos es una realidad constatada, debemos suponer que en un lugar no muy lejano debían fabricarse éstos, aunque repetimos que no tenemos constancia expresa de ello puesto 


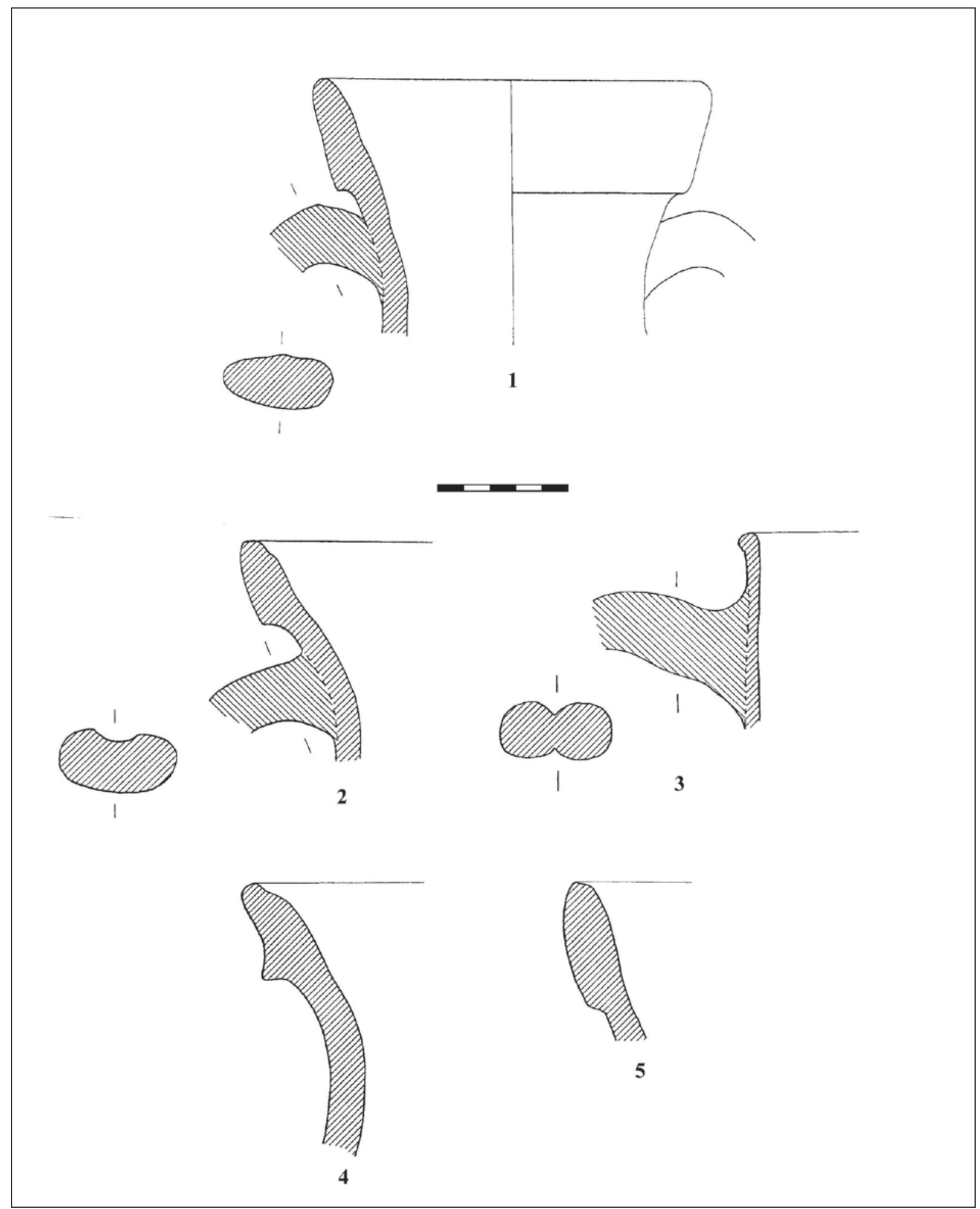

Figura 10: Conjunto anfórico tardorrepublicano relacionado con la amortización del horno (U-E. 5) (mediados del s. I a.C.). 1-2. Haltern 70 antiguas. 3. Dressel 2-4. 4. ¿Ovoide gaditana antigua? ó Dressel 7. 5. Posible Haltern 70 ó Dressel 20 antigua. (Dibujos: Ana Ma Niveau de Villedary y Mariñas). 


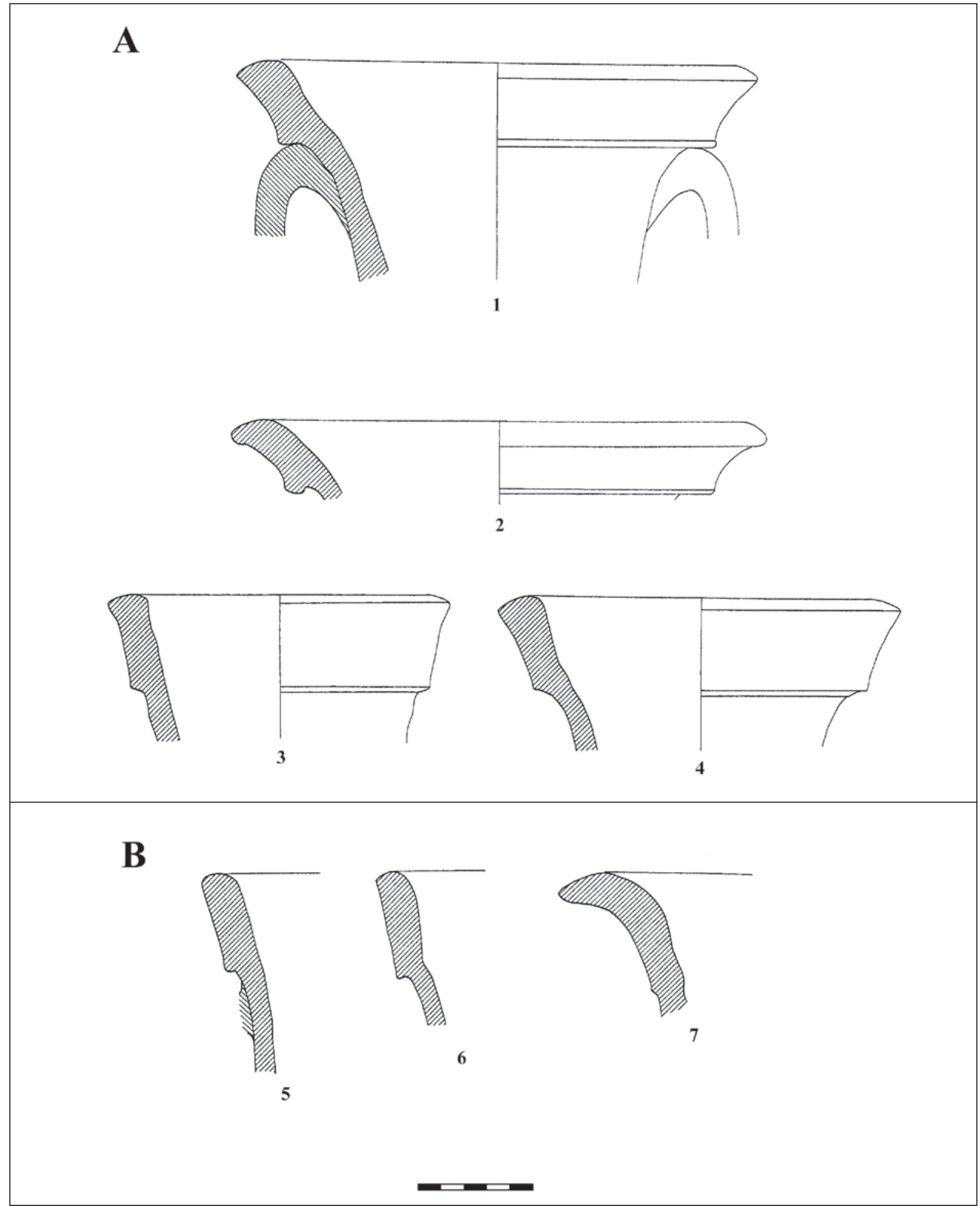

Figura 11: Conjunto anfórico altoimperial procedente de la colmatación del horno (niveles superiores de las U.E. 11 y U.E. 8) (finales del s. I a.C.- principios s. I d.C.). A. Relleno de la fosa (U.E. 11). 1. Dressel 12. 2. Dressel 7/11. 3-4. ¿Dressel 7/11? B. Relleno de la cámara del horno (U.E. 8). 5-6. Haltern 70 de época augústea. 7. Beltrán IIB (Dibujos: Ana Mª Niveau de Villedary y Mariñas). 
que en las inmediaciones no existen evidencias ni de la existencia de otras estructuras de combustión, testares o fallos de cocción, ni tan siquiera de una presencia significativa de ánforas que pudiera llevarnos a pensar que el alfar de la Calle Troilo se inserta en un complejo industrial alfarero y/o salazonero de mayores dimensiones como el documentado en la C/ Gregorio Marañón (Blanco 1991), donde junto a una pileta hidráulica para salar el pescado se documentó una fosa de vertido con desechos de ánforas del tipo T-7.4.3.3.

Otras formas son minoritarias y bien pudieron pertenecer a los alfareros. Es el caso del mortero, pieza única que apareció completa entre los restos del horno (Fig. 4,6 ) y que se pudo utilizar para machacar o mezclar arcillas y pigmentos, sin descartar un uso doméstico, en las actividades cotidianas de los trabajadores. El resto de los elementos documentados, urnas, jarras, etc., podrían haberse fabricado en el horno para su utilización como recipientes cinerarios, aunque más probablemente, dado que son formas escasamente representadas y morfológicamente variadas, se trate de menaje personal del alfar.

En otras ocasiones, al tratar de ciertas producciones vasculares púnicas nos hemos hecho eco de la posibilidad de la existencia de la fabricación de cerámicas "en serie" destinadas en exclusiva a cubrir las necesidades de la necrópolis y del culto (Niveau de Villedary 2003: 25-26). Llegábamos a esta conclusión al advertir que en depósitos cerrados como son las fosas y pozos rituales, muy frecuentes en la necrópolis púnica y tardopúnica de Cádiz, existían un buen número de fragmentos cerámicos que a primera vista parecía que pertenecían a un mismo ejemplar, dada la similitudes técnicas y morfológicas que presentaban pero que tras un estudio más exhaustivo se demostraba que correspondían a un número significativo de piezas distintas. En algunas producciones concretas, como en el caso de la cerámica helenística local o "tipo Kuass", existen otros indicios que confirman esta impresión, como la decoración estampillada típica de estos vasos que en la necrópolis repiten esquemas y estilos, frente a la mayor variedad estilística de otros contextos. Puesto que las prescripciones litúrgicas semitas conllevan la inutilización (ruptura y enterramiento) de la vajilla una vez empleada en los ritos sagrados, esto implica una gran demanda de recipientes cerámicos, que debieron fabricarse en las cercanías de las necrópolis y lugares de culto. La existencia de algunos rituales en los que intervenían un número elevado de fieles supone, al mismo tiempo, la necesidad de abastecerse con rapidez y facilidad de los elementos necesarios para el desarrollo del rito, de ahí la existencia de alfares situados junto a templos y cementerios y la explicación al hallazgo de amplias series cerámicas en fosas y pozos.

Gracias a la excavación de esta pequeña estructura de combustión contamos con nuevos datos para apoyar nuestra argumentación. Especialmente significativo es el caso de los "pebeteros en forma de cabeza femenina", de los que hemos podido diferenciar dos series cada una de ellas representada por dos ejemplares- según el molde utilizado. También entre las producciones mayoritarias de cuencos-tapaderas, opérculos y, sobre todo, de "cubiletes" existe una uniformidad manifiesta que denota la producción de cerámica "en serie", aunque debido a la condición más "artesanal" que "industrial" de estos pequeños talleres, son normales las pequeñas variaciones en la talla y forma .

La ubicación de alfares junto a las necrópolis es frecuente en el mundo fenicio-púnico, en tanto en cuanto que en ambos casos se trata de instalaciones suburbanas, situadas generalmente fuera del perímetro de la ciudad propiamente dicha. Contamos con ejemplos similares en Sicilia donde las necrópolis se ubican con frecuencia en las proximidades de los establecimientos productivos cerámicos, por ejemplo en Mozia y Solunto (Spanò-Giammellaro 2004: 212).

De cualquier forma, templos y necrópolis no debieron surtirse únicamente de los artículos fabricados en los talleres anejos, como prueba la producción del Horno 5 (el de menor tamaño) de Torre Alta, al parecer destinado en exclusiva a la producción de categorías no vasculares como terracotas, discos estampillados y cerámicas engobadas (Sáez Romero et alii 2004: 108-109).

\section{CONCLUSIONES. CONTINUIDAD PÚNICA EN LA ESFERA FUNERARIO- RELIGIOSA DE LA CÁDIZ REPUBLICANA}

Hoy en día es un hecho unánimemente admitido que la derrota púnico-cartaginesa frente a Roma en la Segunda Guerra Púnica no supuso una ruptura brusca ni traumática en las estructuras socioeconómicas de los territorios afectados. A pesar de que desde ese momento las ciudades fenicias entraron a formar parte de iure del territorio romano, de facto no hubo grandes transformaciones, al menos en una primera etapa que se prolonga durante todo el s. II y buena parte del I a.C. (Chaves, García Vargas y Ferrer 1998: 1310-1311).

Las favorables condiciones del foedus del 206 a.C. por el que Gadir conservaba sus propias instituciones, sus costumbres, su capacidad legislativa, el derecho a emitir moneda y a comerciar libremente (López Castro 1991), permitieron a los gaditanos continuar con su 
principal actividad económica, la fabricación y el comercio de las salazones, reactivada en la segunda mitad del s. III gracias a la política llevada a cabo por los bárcidas (Montero et alii 2004: 415). Esta situación queda reflejada arqueológicamente en la continuidad de la mayor parte de los saladeros ${ }^{19}$ y de las instalaciones alfareras ${ }^{20}$ preexistentes que prosiguen su actividad sin apenas modificaciones, de hecho se siguen fabricando los tipos púnicos tradicionales (Ramón 2004: 64-65), sin más cambios que los dictados por la propia evolución morfológica ${ }^{21}$.

En este sentido, trabajos recientes han demostrado la existencia de una clara continuidad a nivel productivo durante todo el s. II a.C. (García Vargas 2004), pudiéndose hablar incluso de una "reactivación" de la industria salazonera en estos momentos (García Vargas 2004: 110). Será en el ámbito de la difusión y comercialización de los productos donde tengan lugar las primeras transformaciones (García Vargas 2004: 108). A los tradicionales circuitos comerciales púnicos se suman a partir de este momento líneas de exportación alternativas. Los productos gaditanos llegan ahora, por vía de los negotiatores itálicos, a nuevos mercados como los campamentos militares y las fundaciones romanas de la Península Ibérica, aunque no se abandonan los antiguos circuitos ${ }^{22}$.

Por su parte, la llegada masiva de manufacturas ajenas a la tradición local -fundamentalmente vajilla campaniense y recipientes anfóricos- se ha explicado en

19. Como reflejan algunos estudios recientes ( $c f$. Lagóstena 2001: 216-221), la industria pesquera y salazonera queda limitada durante el s. II a.C. y sobre todo en su primera mitad a la franja costera de tradición fenicio-púnica que transcurre de Cádiz a Cartagena y es sólo a partir de este momento cuando se asiste a una paulatina reorganización de los patrones de asentamiento y de producción. Fundaciones como la de Baelo resultan paradigmáticas en este sentido.

20. Una síntesis actualizada de los alfares activos durante el s. II a.C. en la Isla de León en: Montero et alii 2004.

21. Esta continuidad productiva está constatada en los alfares isleños de Torre Alta (por último, Sáez Romero 2004) y Pery Junquera (Bustamante y Martín Arroyo 2004; Carretero 2004) donde la producción no sólo continúa sino que se reactiva. Los tipos anfóricos púnicos tradicionales del s. III evolucionan y dan lugar a las morfologías propias del II. Ahora las T-9.1.1.1. sustituyen a las T-8.2.1.1., las T-12.1.1.2 a las T-12.1.1.1 y T-12.1.1.1/2. Se siguen copiando envases itálicos: grecoitálicas tardías y Dressel 1A, 1B y 1C (Sáez y Díaz 2003) y comienza la producción de T-7.4.3.3., a semejanza de los recipientes tardíos cartagineses. Otras producciones, como la de Barniz Rojo púnico-gaditano "tipo Kuass" también continúan (Niveau de Villedary 2004b), aunque evolucionan incorporando "nuevas" formas de sabor itálico y empezando a recubrir sus superficies con tonalidades oscuras en lugar del tradicional color rojo púnico.

22. Es este paulatino cambio en los mercados, rutas y agentes del comercio lo que a la postre termine por "romanizar" las estructuras industriales púnicas, hecho que se hace patente desde mediados del s. I a.C. y se configura plenamente en época imperial. función de la vitalidad del comercio itálico y de la apertura de nuevas rutas entre la península Ibérica e Italia tras la derrota cartaginesa en la Segunda Guerra Púnica. Aunque no hay que olvidar que la mayor parte de estas mercancías estaban destinadas, sobre todo en los momentos iniciales, a abastecer a las legiones destacadas en la península (García Vargas y Ferrer 2001: 36-37).

Si las estructuras económicas no parecen experimentar cambios significativos hasta mediados del s. I a.C., también en otros aspectos como los comportamientos rituales y funerarios, tradicionalmente conservadores, se observa una continuidad muy marcada respecto a momentos precedentes. La pervivencia de las costumbres funerarias púnicas queda plasmada en la continuidad espacial y material de la necrópolis (Niveau de Villedary 2001: 190), donde no se observa ruptura alguna entre los niveles de finales del s. III y los de comienzos del II a.C. ${ }^{23}$ Se siguen utilizando las mismas estructuras rituales (pozos y fosas que se rellenan con los restos de los banquetes) y aunque surgen algunas nuevas (piletas) todo parece indicar que se construyen para su uso en ritos tradicionales semitas. La composición de los ajuares (ungüentarios de tipología helenística, askoi zoomorfos, cerámica común local), como han advertido otros autores (García Vargas y Ferrer 2001: 36), también nos remiten a costumbres funerarias feniciopúnico, al igual que algunos contextos rituales fechados a comienzos del s. II, donde existen evidencias de la realización de prácticas cultuales de raigambre oriental con presencia de cerámicas de tradición púnica (vasos "tipo Kuass" evolucionados) junto a elementos de la vajilla itálica de barniz negro (campaniense A) y "pebeteros en forma de cabeza femenina" (Niveau de Villedary y Córdoba 2003, passim.)

La evidencia material nos lleva a sostener sin ningún género de dudas que los habitantes de Cádiz en el s. II a.C. siguen sintiendo y continúan enterrándose como semitas, circunstancia que sólo variará cuando culmine el proceso de pérdida de identidad étnica de los gaditanos, lo que generalmente se sitúa hacia mediados del s. I a.C. (López Castro 2002: 241). Este hecho es la culminación del proceso paulatino de asimilación de las elites provinciales mediante la adopción de elementos culturales romanos como la lengua, la escritura y la religión (López Castro 2002: 248-249).

23. A este respecto, resulta ilustrativo un conjunto funerario excavado por uno de nosotros (F.J.B.J.) en el año 2000. Los enterramientos, que aparecen agrupados en una gran fosa delimitada por un muro en el que se abre un acceso, pertenecen al menos a tres generaciones distintas y se fechan, por la tipología de las tumbas y los materiales cerámicos asociados, entre finales del s. III y principios del II a.C. (Blanco 2000: 39 ss.). 
En este largo proceso de integración ${ }^{24}$ política, social y económica que llega prácticamente hasta el Imperio (López Castro 2002: 241) asistimos hacia mediados del s. II a.C. a un cierto florecimiento púnico que se ha puesto en relación con la llegada física de efectivos cartagineses tras la definitiva derrota de Cartago frente a Roma (146 a.C.). No se trata de un fenómeno aislado, sino que por el contrario es una situación común a la mayoría de las áreas de arraigada cultura fenicio-púnica como por ejemplo en Cerdeña (Bondì 1990: 462). Es ahora cuando se introducen modelos de tradición semita, pero ajenos en principio al repertorio gaditano como los "pebeteros en forma de cabeza femenina", los askoi zoomorfos o las ánforas incluidas en el grupo $\mathrm{C}$ de Mañá 25 , formas que los talleres gaditanos reproducen y que conocen un considerable éxito, tanto los envases comerciales como las figuras de culto.

Es en este contexto de lentas -aunque imparablestransformaciones cuando podemos situar la producción del horno de la calle Troilo. Se trata como hemos visto de una estructura a caballo entre ambas realidades, entre el final del mundo púnico y la plena incorporación al estado romano: momento en el que todavía conviven las dos tradiciones, la púnica manifiesta en la morfología arcaizante de la estructura de combustión y en la fabricación de elementos cultuales tardopúnicos y la romana, puesto que el resto de las formas fabricadas denota la plena asimilación de la cultura material itálica.

No es casualidad que sean precisamente los objetos vinculados a la religión y el culto, los aspectos más conservadores de una sociedad y los que más tardan en desaparecer o asimilarse a los nuevos, los que aún conserven el sabor púnico; lo que nos demuestran es una pervivencia (que no tardará en desaparecer) de las creencias más profundas semitas, mientras que en los demás aspectos materiales se han sustituido ya unas formas por otras.

De hecho, el final del funcionamiento del horno y su amortización final, que hemos situado hacia mediados del s. I a.C., hay que ponerlos en relación con la reforma urbana de Balbo el Menor que literalmente

24. En la actualidad, se prefiere hablar en términos de "transformación" paulatina e "integración" de las estructuras púnicas en las romanas como un fenómeno de larga duración (Chaves, García Vargas y Ferrer 1998: 1310) aunque imparable, desterrando conceptos historiográficos tan arraigados como "romanización" o "pervivencias púnicas", fruto de una visión "romanocéntrica" que "nos dificulta ver a los conquistados por Roma, en este caso los fenicios occidentales, como sujetos de su propia historia" (López Castro 2002: 243).

25. Un ejemplo gráfico de esta "transformación" paulatina y de la convivencia entre ambas tradiciones lo encontramos en las estampillas de las ánforas T-7.4.3.3. del vertedero de la C/ Gregorio Marañón, con grafía tanto latina como tardopúnica (Blanco 1991). "arrasa" la estructura y que supone la ampliación de la ciudad a costa del antiguo cinturón periurbano ocupado hasta el momento por la necrópolis y por pequeñas instalaciones fabriles.

\section{BIBLIOGRAFÍA}

ADROHER AUROUX, A. Ma. (1993): “Céramique commune punique", Lattara 6: 374-378. Lattes.

ALFARO, C. (1988): Las monedas de Gadir/Gades. Madrid, Fundación para el Fomento de los Estudios Numismáticos.

AQUILUÉ ABADÍAS, X.; GARCÍA ROSELLÓ, J. y GUITART DURÁN, J. (coords.) (2000): Actas de la Taula Rodona: La ceràmica de vernís negre dels segles II i I a.C: Centres productors mediterranis $i$ comercialització a la Península Ibèrica (Empúries, 1998). Mataró, Patronat Municipal de Cultura.

ARTEAGA MATUTE, O.; CASTAÑEDA FERNÁNDEZ, V.; HERRERO LAPAZ, N. y PÉREZ RODRÍGUEZ, M. (2001): “Los hornos tardopúnicos de Torre Alta (San Fernando, Cádiz)", Anuario Arqueológico de Andalucía, 1997 III: 128-136.

BALDOMERO, A.; CORRALES, P.; ESCALANTE, M. M.; SERRANO, E. y SUÁREZ, J. (1997): “El alfar romano de la Huerta del Rincón: Síntesis tipológica y momentos de producción", Figlinae Malacitanae. La producción romana en los territorios malacitanos: 147-176. Málaga, Área de Arqueología. Universidad de Málaga.

BELÉN DEAMÓS, Mª; CONLIN, E. y ANGLADA, R. (2001): "Cultos betílicos en Carmona Romana", Arys 4: 141-164.

BELTRÁN, M. (1990): Guía de la cerámica romana. Zaragoza, Libros Pórtico.

BENABAT HIERRO, Y. y PÉREZ MACÍAS, J. A. (1999): "La Ollita, una noria islámica en Niebla", Huelva en su Historia, $2^{a}$ época 7: 233-243.

BERNAL CASASOLA, D.; DÍAZ RODRÍGUEZ, J. J.; EXPÓSITO ÁlVAREZ, J. Á.; SÁEZ ROMERO, A. Ma ; LORENZO MARTÍNEZ, L. y SÁEZ ESPLIGARES, A. (2003): Arqueología y Urbanismo. Avance de los hallazgos de época púnica y romana en las obras de la carretera de Camposoto (San Fernando, Cádiz). Cádiz, Servicio de Publicaciones, Universidad de Cádiz. Gerencia Municipal de Urbanismo, Ayuntamiento de San Fernando.

BERNAL CASASOLA, D.; LORENZO MARTÍNEZ, L.; EXPÓSITO ÁLVAREZ, J. Á.; SÁEZ ROMERO, A. Ma y DÍAZ RODRÍGUEZ, J. J. (2004a): "Las innovaciones tecnológicas itálicas en la alfarería 
gadirita (s. II a.C.). A propósito del taller anfórico de la Avda. de Portugal", BERNAL CASASOLA, D. y LAGÓSTENA BARRIOS, L. (eds.), Actas del Congreso Internacional Figlinae Baeticae. Talleres alfareros y producciones cerámicas en la Bética Romana (ss. II a.C.-VII d.C.) (= British Archaeological Reports International Series 1266, II): 621632. Oxford, Universidad de Cádiz.

BERNAL CASASOLA, D.; DÍAZ RODRÍGUEZ, J. J.; EXPÓSITO ÁlVAREZ, J. Á.; SÁEZ ROMERO, A. $M^{\mathrm{a}}$. y LORENZO MARTÍNEZ, L. (2004b): "Los hornos púnicos de praefurnium escalonado (ss. III y II a.C.). Reflexiones a raíz del alfar de La Milagrosa (San Fernando, Cádiz)", BERNAL CASASOLA, D. y LAGÓSTENA BARRIOS, L. (eds.), Actas del Congreso Internacional Figlinae Baeticae. Talleres alfareros y producciones cerámicas en la Bética Romana (ss. II a.C.-VII d.C.) (= British Archaeological Reports International Series 1266, II): $607-$ 620. Oxford, Universidad de Cádiz.

BERNAL CASASOLA, D. y LAGÓSTENA BARRIOS, L. (eds.) (2004): Actas del Congreso Internacional Figlinae Baeticae. Talleres alfareros y producciones cerámicas en la Bética Romana (ss. II a.C. - VII d.C.) (=British Archaeological Reports International Series 1266, II): 621-632. Oxford, Universidad de Cádiz.

BLANCO JIMÉNEZ, F. J. (1991): "Excavaciones de urgencia en un solar de la calle Gregorio Marañón. Cádiz”, Anuario Arqueológico de Andalucía, 1989 III: 78-81.

- (1999a): Informe arqueológico de la intervención arqueológica realizada en la calle Troilo $n^{\circ} 5$ (Cádiz - febrero 1999) (= Memoria inédita depositada en la Delegación Provincial de Cultura de Cádiz). Cádiz.

- (1999b): Informe arqueológico de los resultados obtenidos en la primera fase de excavación arqueológica en los solares ubicados en la Calle Marqués de la Ensenada (antiguos Cuarteles de Varela). Julio de 1999 (= Memoria inédita depositada en la Delegación Provincial de Cultura de Cádiz). Cádiz.

- (2000): Informe-memoria de las excavaciones arqueológicas efectuadas en las parcelas: 40 V.P.P., Locales, garajes y oficinas (Fase 2) (C/Marqués de la Ensenada y Avda. de la Constitución 1812). Cádiz. 18 V.P.O., locales y garajes (C/ Marqués de la Ensenada) UE-EX-6 Cuarteles de Varela. Cádiz (= Informe Inédito depositado en la Delegación Provincial de Cultura de Cádiz). Cádiz.

BONDI', S. F. (1990): “La cultura punica nella Sardegna romana: un fenomeno di sopravvivenza?"
MASTINO, A. (ed.), L'Africa romana. Atti del VII convegno di studio (Sassari, 1989): 457-464. Sassari.

BUSTAMENTE ÁLVAREZ, M. y MARTÍN-ARROYO SÁNCHEZ, D. (2004): "La producción de ánforas greco-itálicas de imitación y su evolución en la bahía gaditana durante el siglo II a.C.: los contextos de la Avda. Pery Junquera en San Fernando (Cádiz)", BERNAL CASASOLA, D. y LAGÓSTENA BARRIOS, L. (eds.), Actas del Congreso Internacional Figlinae Baeticae. Talleres alfareros y producciones cerámicas en la Bética Romana (ss. II a.C.-VII d.C.) (=British Archaeological Reports International Series 1266, II): 441-446. Oxford, Universidad de Cádiz.

CARRETERO POBLETE, P. A. (2004): "Las producciones cerámicas de ánforas tipo "Campamentos Numantinos" y su origen en San Fernando (Cádiz): Los hornos de Pery Junquera", BERNAL CASASOLA, D. y LAGÓSTENA BARRIOS, L. (eds.), Actas del Congreso Internacional Figlinae Baeticae. Talleres alfareros y producciones cerámicas en la Bética Romana (ss. II a.C.-VII d.C.) (= British Archaeological Reports International Series 1266, II): 427-440. Oxford, Universidad de Cádiz.

CASTAÑEDA FERNÁNDEZ, V. y HERRERO LAPAZ, N. (2001): "Intervención arqueológica de urgencia en los entornos de los hornos tardopúnicos de Torre Alta (San Fernando, Cádiz). Sondeos arqueológicos en la Unidad de ejecución n ${ }^{\circ} 16$." Anuario Arqueológico de Andalucía, 1998 III (I): 134-137.

CHAVES TRISTÁN, F.; GARCÍA VARGAS, E. y FERRER ALBELDA, E. (1998): "Datos relativos a la pervivencia del denominado "Círculo del Estrecho" en época republicana", L'Africa Romana. Atti del XII Convegno di Studio (Olbia, 1996): 1307-1320. Sassari.

CHIC GARCÍA, G. (1984): “Lebrillos y macetas en los antiguos alfares romanos del Guadalquivir y del Genil", Habis 15: 275-280.

CLAVAÍN GONZÁLEZ, I. y SÁEZ ROMERO, A. (2003): "La intervención arqueológica de urgencia en el residencial David Fase II (UE 55) de El Pedroso (San Fernando, Cádiz)", Anuario Arqueológico de Andalucía, 2000 III, 1 (Actividades de Urgencia): 174-182.

FERRER ALBELDA, E. (1995-1996): “Anotaciones sobre el taller cerámico de Gadir", Boletín del Museo de Cádiz VII: 63-76.

— ; SIBÓN OLANO, F. y MANCHEÑO SAGRARIO, D. (2000): "Máscaras púnicas de Gadir", Actas del IV Congreso Internacional de Estudios Fenicios y 
Púnicos (Cádiz, 1995) II: 593-605. Cádiz, Universidad de Cádiz.

FRUTOS REYES, G. DE y MUÑOZ VICENTE, A. (1994): "Hornos púnicos de Torre Alta (San Fernando, Cádiz)", Arqueología en el entorno del Bajo Guadiana: 393-414. Huelva, Universidad de Huelva.

- (1996): "La industria pesquera y conservera púnico-gaditana: Balance de la investigación. Nuevas perspectivas", Spal 5: 133-165. http://dx.doi. org/10.12795/spal.1996.i5.07

GAGO VIDAL, Mํ. H.; CLAVAIIN GONZÁLEZ, I.; MUÑOZ VICENTE, A.; PERDIGONES MORENO, L. y FRUTOS REYES, G. DE (2000): "El complejo industrial de salazones gaditano de Camposoto, San Fernando (Cádiz): Estudio preliminar", Habis 31: 37-61.

GARCÍA JIMÉNEZ, I.; ZULETA ALEJANDRO, F. y PRIETO REINA, O. (2004): "El yacimiento romano de El Torno-Cementerio de San Isidro del Guadalete", BERNAL CASASOLA, D. y LAGÓSTENA BARRIOS, L. (eds.), Actas del Congreso Internacional Figlinae Baeticae. Talleres alfareros y producciones cerámicas en la Bética Romana (ss. II a.C.-VII d.C.) (= British Archaeological Reports International Series 1266, II): 663-666. Oxford, Universidad de Cádiz.

GARCÍA VARGAS, E. (1998): La producción de ánforas en la Bahía de Cádiz en época romana (siglos II a.C. - IV d.C.). Ecija, Ed. Gráficas Sol.

- (2001): "Pesca, sal y salazones en las ciudades fenicio-púnicas del Sur de Iberia", De la Mar y de la Tierra. Producciones y productos fenicio-púnicos. XV Jornadas de Arqueología fenicio-púnica (Eivissa, 2000) (= Trabajos del Museo Arqueológico de Ibiza 47): 9-66. Eivissa, Museu Arqueologic d'Eivissa e Formentera.

— (2004): "La romanización de la "industria" púnica de las salazones en el sur de Hispania", Actas de los XVI Encuentros de Historia y Arqueología. Las industrias alfareras y conserveras fenicio-púnicas de la bahía de Cádiz (San Fernando, 2000): 101-129. Córdoba, Publicaciones Obra Social y Cultural Cajasur - Fundación de Cultura, Ayuntamiento de San Fernando.

- y FERRER ALBELDA, E. (2001): "Las salazones de pescado en la Gadir púnica: Estructuras de producción”, Laverna XII: 21-41.

GENER BASALLOTE, J. Ma. (1999): “Seguimiento arqueológico en la obra de alcantarillado en la calle Santa Cruz de Tenerife y Avda. de Andalucía (Cádiz)", Anuario Arqueológico de Andalucía, 1994 III: $16-20$.

GONZÁLEZ TORAYA, B.; TORRES QUIRÓS, J.; LAGÓSTENA BARRIOS, L. y PRIETO REINA, O. (2000): "Los inicios de la producción anfórica en la Bahía gaditana en época republicana: La intervención de urgencia en Avda. Pery Junquera (San Fernando, Cádiz)", Actas del Congreso Internacional Ex Baetica Amphorae. Conservas, aceite y vino de la Bética en el Imperio Romano. (Sevilla-Ecija, diciembre 1998) I: 175-185. Écija, Ed. Gráficas Sol.

GUTIÉRREZ LÓPEZ, J. Ma . (2000): “Aportaciones a la producción de salazones de Gadir: La factoría púnico-gaditana 'Puerto 19'”, Revista de Historia de El Puerto 24: 11-46.

- (2001): "La factoría de salazones púnico-gaditana "Puerto 19" de Pinar Hondo (El Puerto de Santa María, Cádiz)", Anuario Arqueológico de Andalucía, 1997 III, 1 (Actividades de Urgencia): 77-87.

LAGÓSTENA BARRIOS, L. (1994): “Alfarerías romanas de El Puerto de Santa María. Un modelo de transición económica del ámbito cultural púnico al romano en la bahía gaditana", Revista de Historia de El Puerto 13: 9-41.

- (1996): Alfarería romana en la Bahía de Cádiz. Cádiz, Universidad de Cádiz.

- (2001): La producción de salsas y conservas de pescado en la Hispania Romana (II a.C.-VI d.C.) (= Col.lecció Instrumenta 11). Barcelona, Universitat de Barcelona.

- y BERNAL CASASOLA, D. (2004): "Alfares y producciones cerámicas en la provincia de Cádiz. Balance y perspectivas", BERNAL CASASOLA, D. y LAGÓSTENA BARRIOS, L. (eds.), Actas del Congreso Internacional Figlinae Baeticae. Talleres alfareros y producciones cerámicas en la Bética Romana (ss. II a.C.-VII d.C.) (= British Archaeological Reports International Series 1266, I): 39-124. Oxford, Universidad de Cádiz.

LÓPEZ CASTRO, J. L. (1991): "El foedus de Gadir del 206 a.C.: Una revisión", Florentia Iliberritana 2: 269-280.

- (2002): "Las ciudades de fundación fenicia en el sur de Hispania: integración y pervivencias durante el Alto Imperio", GONZÁLEZ ROMÁN, C. y PADILLAARROBA, Á. Estudios sobre las ciudades de la Bética: 241-262. Granada, Universidad de Granada.

LÓPEZ DE LA ORDEN, Mª D. (2003): "Urnas cinerarias de la necrópolis romana de Cádiz", Anuario Arqueológico de Andalucía 2000, II (Actividades Sistemáticas y Puntuales): 111-116.

MANNONI, T. y GIANNICHEDDA, E. (2004): Arqueología de la producción (= Ariel Prehistoria). Barcelona, Ed. Ariel.

MONTERO FERNÁNDEZ, A. I.; MONTERO FERNÁNDEZ, R.; SÁEZ ROMERO, A. Mª y DÍAZ RODRÍGUEZ， J. J. (2004): "Innovaciones, 
transformaciones y pervivencias. Evolución de la alfarería gadirita durante los ss. III-II a.n.e.” BERNAL CASASOLA, D. y LAGÓSTENA BARRIOS, L. (eds.), Actas del Congreso Internacional Figlinae Baeticae. Talleres alfareros y producciones cerámicas en la Bética Romana (ss. II a.C.-VII d.C.) (= British Archaeological Reports International Series 1266, II): 413-426. Oxford, Universidad de Cádiz.

MUÑOZ VICENTE, A. (1992): "En torno a seis askoi zoomorfos de la necrópolis púnica de Cádiz", Boletín del Museo de Cádiz V: 7-15.

- ; FRUTOS REYES, G. DE y BERRIATÚA HERNÁNDEZ, N. (1988): “Contribución a los orígenes y difusión comercial de la industria pesquera y conservera gaditana a través de las recientes aportaciones de las factorías de salazones de la Bahía de Cádiz", $A c$ tas del I Congreso Internacional El Estrecho de Gibraltar (Ceuta, 1987) I: 487-508. Madrid, U.N.E.D.

- y FRUTOS REYES, G. DE (2004): “El comercio de las salazones en época fenicio-púnica en la bahía de Cádiz. Estado actual de las investigaciones: los registros arqueológicos", Actas de los XVI Encuentros de Historia y Arqueología. Las industrias alfareras y conserveras fenicio-púnicas de la bahía de Cádiz (San Fernando, 2000): 131-167. Córdoba, Publicaciones Obra Social y Cultural Cajasur - Fundación de Cultura, Ayuntamiento de San Fernando.

NIVEAU DE VILLEDARY Y MARIÑAS, A. Ma (2001): "Pozos púnicos en la necrópolis de Cádiz: Evidencias de prácticas rituales funerarias", Rivista di Studi Fenici XXIX, 2: 183-230.

— (2003): "El uso ritual de la vajilla cerámica en la necrópolis púnica de Cádiz", Archivo Español de Arqueología 76: 3-30.

- (2004a): "Evidencias de la producción de cerámicas barnizadas "tipo Kuass" en la bahía de Cádiz", Actas de los XVI Encuentros de Historia y Arqueología. Las industrias alfareras y conserveras fenicio-púnicas de la bahía de Cádiz (San Fernando, 2000): 171-195. Córdoba, Publicaciones Obra Social y Cultural Cajasur - Fundación de Cultura, Ayuntamiento de San Fernando.

- (2004b): "La producción de barniz púnico-gaditano en el s. II a.C. Nuevos datos aportados por el conjunto alfarero de Pery Junquera (San Fernando, Cádiz)", BERNAL CASASOLA, D. y LAGÓSTENA BARRIOS, L. (eds.), Actas del Congreso Internacional Figlinae Baeticae. Talleres alfareros y producciones cerámicas en la Bética Romana (ss. II a.C. - VII d.C.) (= British Archaeological Reports 1266): 677-690. Oxford,

- (2007): "Nuevos datos sobre la presencia de "pebeteros en forma de cabeza femenina" en la Bahía de
Cádiz”, MARÍN CEBALLOS, Mª.C. y HORN, F. (eds.), Imagen y culto en la Iberia prerromana. En torno a los llamados "pebeteros en forma de cabeza femenina”. Seminario de la Casa de Velázquez (Madrid, 2004) (= Spal Monografias IX):151-194. Sevilla, Universidad de Sevilla.

- y CÓRDOBA ALONSO, I. (2003): “Algunas consideraciones sobre la religiosidad de Gadir. Nuevos datos para su estudio", Saguntum 35: 123-145.

OLCESE, G. (2003): Ceramiche comuni a Roma e in area romana: Produzione, circolazione e tecnologia (Tarda Età Repubblicana - Prima Età Imperiale (=Documenti di Archeologia 28). Mantova, Società Archeologica Padana s.r.l.

PENA, Ma . J. (1990): “Consideraciones sobre iconografía mediterránea: Los pebeteros en forma de cabeza femenina", MOLL BLANES, I. (ed.), La Mediterrània. Antropologia i Història. VII Jornades d'Estudis Històrics Locals (Palma, 1988): 55-66. Palma.

PERDIGONES MORENO, L. y MUÑOZ VICENTE, A. (1990): "Excavaciones arqueológicas de urgencia en los hornos púnicos de Torre Alta. San Fernando, Cádiz", Anuario Arqueológico de Andalucía, 1988 III: 106-112.

QUINTERO ATAURI, P. (1932): Excavaciones de Cádiz. 1929-31 (= Memorias de la Junta Superior de Excavaciones y Antigüedades 117). Madrid.

RAMÓN TORRES, J. (2004): “La producción anfórica gaditana en época fenicio-púnica", Actas de los XVI Encuentros de Historia y Arqueología. Las industrias alfareras y conserveras fenicio-púnicas de la bahía de Cádiz (San Fernando, 2000): 63-100. Córdoba, Publicaciones Obra Social y Cultural Cajasur - Fundación de Cultura, Ayuntamiento de San Fernando.

RODERO RIAZA, A. (1995): Las ánforas prerromanas en Andalucía (=Epigrafía e Antichità 13). Faenza.

RUIZ GIL, J. A. (1987): "Sondeos Arqueológicos de urgencia para la delimitación de las factorías de salazones púnico-gaditanas de El Puerto de Santa María, Cádiz", Anuario Arqueológico de Andalucía, 1986 III: 101-105.

- (1991): "Cronología de las factorías de salazones púnicas de Cádiz", Atti del II Congresso Internazionale di Studi Fenici e Punici (Roma, 1987) III: 1211-1214. Roma.

SÁENZ GÓMEZ, M. A. y PERDIGONES MORENO, L. (1991): "Excavaciones arqueológicas de urgencia en un solar de la calle Acacias esq. Santa Cruz de Tenerife. Extramuros de Cádiz", Anuario Arqueológico de Andalucia, 1989 III: 82-86.

SÁEZ ESPLIGARES, A. (1994): “Aproximación a la historiografía de la Prehistoria y Arqueología Cásica 
en San Fernando", RAMOS MUÑOZ, J.; SÁEZ ESPLIGARES, A.; CASTAÑEDA FERNÁNDEZ, V. y PÉREZ RODRÍGUEZ, M. (coords.), Aproximación a la Prehistoria de San Fernando. Un modelo de poblamiento periférico en la Banda Atlántica de Cádiz: 3951. San Fernando, Ayuntamiento de San Fernando.

SÁEZ ROMERO, A. Ma . (2004): "El alfar tardopúnico de Torre Alta. Resultados de las excavaciones de 2002-03", BERNAL CASASOLA, D. y LAGÓSTENA BARRIOS, L. (eds.), Actas del Congreso Internacional Figlinae Baeticae. Talleres alfareros y producciones cerámicas en la Bética Romana (ss. II a.C.-VII d.C.) (= British Archaeological Reports International Series 1266, II): 649661. Oxford, Universidad de Cádiz.

— y DÍAZ RODRÍGUEZ, J. J. (2003): "Salazones de pescado y vino. A propósito del contenido de algunas ánforas púnico-gadiritas", Texto entregado en el III Simposio da Associação Internacional de História e Civilização da Vinha e do Vinho (Madeira, 2003).

- ; MONTERO FERNÁNDEZ, R.; TOBOSO SUÁREZ, E. J. y DÍAZ RODRÍGUEZ, J. J. (2003): "Control Arqueológico en el yacimiento púnico-romano de Gallineras (San Fernando, Cádiz)", Anuario Arqueológico de Andalucía, 2000 II, 1 (Actividades de Urgencia): 166-173.

- ; MONTERO FERNÁNDEZ, R. y TOBOSO SUÁREZ, E. J. (2004): "Un antecedente centromediterráneo al complejo alfarero púnico de Torre Alta (San Fernando, Cádiz)", Actas de los XVI Encuentros de Historia y Arqueología. Las industrias alfareras y conserveras fenicio-púnicas de la bahía de Cádiz (San Fernando, 2000): 131-167. Córdoba, Publicaciones Obra Social y Cultural Cajasur - Fundación de Cultura, Ayuntamiento de San Fernando.

_ ; SÁEZ ESPLIGARES, A.; MONTERO FERNÁNDEZ, A. I.; DÍAZ RODRÍGUEZ, J. J.; MONTERO FERNÁNDEZ, R.; TOBOSO SUÁREZ, E.; BELIZÓN ARAGÓN, R. y PÉREZ GRAU, C. (2004): "Control arqueológico de urgencia en los hornos púnicos de Torre Alta (San Fernando, Cádiz). Informe preliminar", Anuario Arqueológico de Andalucía 2001 III, 1 (Actividades de Urgencia): 99-110.

SERRANO RAMOS, E. (1997): “La producción cerámica de los talleres romanos de la Depresión de Antequera", Figlinae Malacitanae. La producción romana en los territorios malacitanos: 217-232. Málaga, Área de Arqueología. Universidad de Málaga.
- (2000): Cerámica común romana: siglos II a.C. al VII d.C. Materiales importados y de producción local en el territorio malacitano (= Málaga, Servicio de Publicaciones. Universidad de Málaga.

SPANÒ-GIAMMELLARO, A. (2004): "I luoghi della morte: impianti funerari nella Sicilia fenicia e punica", GONZÁLEZ PRATS, A. (ed.), El mundo funerario. Actas del III Seminario Internacional sobre Temas Fenicios (Guardamar del Segura, 2002): 205252. Alicante, Instituti Alicantino de Cultura "Juan Gil-Albert". Diputación Provincial de Alicante.

VALLEJO SÁNCHEZ, J. I.; CÓRDOBA ALONSO, I. y NIVEAU DE VILLEDARY Y MARIÑAS, A. $M^{a}$. (1999): "Factorías de salazones en la bahía gaditana: Economía y organización espacial", XXIV Congreso Nacional de Arqueología (Cartagena, 1997) 3: 107-114. Murcia,

- y NIVEAU DE VILLEDARY Y MARIÑAS, A. M ${ }^{\mathrm{a}}$. (1999): "Investigación y gestión en la Arqueología Urbana de Cádiz", XXV Congreso Nacional de Arqueología (Valencia, 1999): 348-351. Valencia.

- (2001): "La Arqueología Urbana en Cádiz: dificultades de su gestión", CIRICI NARVÁEZ, J. R. y GARCÍA PAZOS, M. (eds.), Actas de los I Encuentros de Primavera de la Universidad de Cádiz en el Puerto de Santa María. Las tribulaciones en la tutela del Patrimonio paisajístico y urbano (El Puerto de Santa María, 1997) (= Serie Encuentros de Primavera en El Puerto 4): 97-111. El Puerto de Santa María, Ayuntamiento de El Puerto de Santa María.

- (2002): "La Arqueología andaluza a comienzos del s. XXI: Prioridades y tendencias", Actas del III Congreso de Historia de Andalucía (Córdoba, 2001) (= Prehistoria): 468-476. Córdoba, Publicaciones Obra Social y Cultural Cajasur.

VEGAS, M. (1973): Cerámica común romana del Mediterráneo Occidental (= Publicaciones eventuales 22). Barcelona, Instituto de Arqueología y Prehistoria. Universidad de Barcelona.

VV.AA. (2002): Cádiz al fin del milenio. Cinco años de arqueología en la ciudad (1995-2000). Catálogo de la exposición. Cádiz.

- (2004): Actas de los XVI Encuentros de Historia y Arqueología. Las industrias alfareras y conserveras fenicio-púnicas de la bahía de Cádiz (San Fernando, 2000). Córdoba, Publicaciones Obra Social y Cultural Cajasur - Fundación de Cultura, Ayuntamiento de San Fernando. 